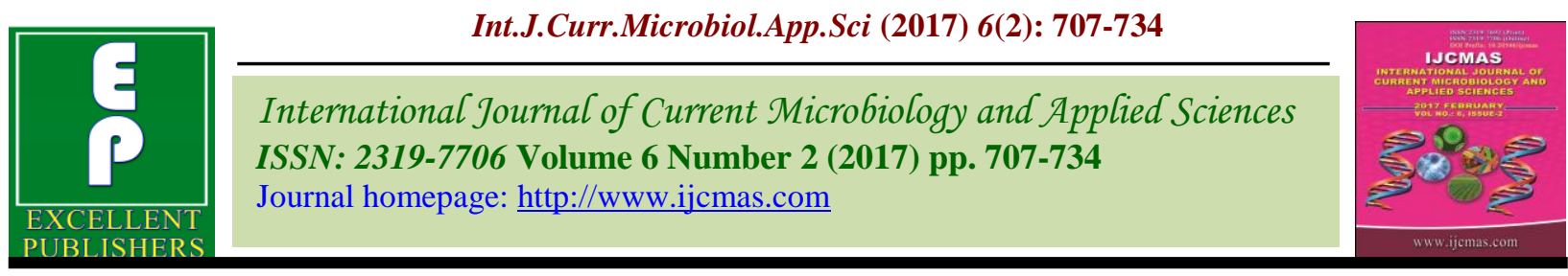

Review Article

http://dx.doi.org/10.20546/ijcmas.2017.602.080

\title{
Conservation Agriculture and Soil Quality- An Overview
}

\author{
M.R. Yadav ${ }^{1}$, C.M. Parihar ${ }^{3}$, Rakesh Kumar ${ }^{1}$, R.K. Yadav², S.L. Jat ${ }^{3}$, \\ A.K. Singh ${ }^{3}$, H. Ram $^{1}$, R.K. Meena ${ }^{1}$, M. Singh ${ }^{1}$, V.K. Meena ${ }^{1}$, \\ N. Yadav', B. Yadav', C. Kumawat ${ }^{2}$ and M.L. Jat ${ }^{5}$ \\ ${ }^{1}$ ICAR- National Dairy Research Institute, Karnal-132001, India \\ ${ }^{2}$ ICAR- Indian Agricultural Research Institute, New Delhi-110 012, India \\ ${ }^{3}$ ICAR- Indian Institute of Maize Research (IIMR), New Delhi-110 012, India \\ ${ }^{4}$ Institute of Agricultural Sciences, Banaras Hindu University, Varanasi-221005, India \\ ${ }^{5}$ International Maize and Wheat Improvement Center, NASC Complex, NewDelhi-110012, India \\ *Corresponding author
}

\section{A B S T R A C T}

\section{Keywords}

Conservation agriculture, Convetional tillage, Soil quality, Soil organic carbon, Soil properties, Soil biodiversity, Residue management, Tillage, and Carbon sequestration.

\section{Article Info}

Accepted:

18 January 2017

Available Online:

10 February 2017
Conservation agriculture (CA) has potential to changes soil physical, chemical and biological soil quality parameters compared to conventional tillage (CT) systems. The improved bio-physico-chemical soil quality in turn, affect the ecosystem services and sustainability of crop production system through counterbalancing the climate variability with the help of increasing sink for carbon sequestration within the soil. CA can also affect the functional diversity of soil microbes that essential for improved soil quality, crop production and many ecosystem services. In this context, we summarize the current status of know how CA and about the gaps in understanding, and highlight some research priorities for improving soil quality using CA practices. The review comprises of studies from diverse soil and ecologies of the world. There is clear evidence that CA improves soil physical quality by favouring soil aggregation, soil hydraulic conductivity, bulk density (BD) compared to CT. The combination of zero tillage (ZT) with crop residue retention increases chemical quality by improving the soil organic carbon (SOC) storage and macro and micro nutrient dynamics. Long term adoption of $\mathrm{CA}$ and residue management has a significant impact on soil fauna and flora communities under diversified crop rotations. The different soil microbes group responds differently to tillage disturbance and changed residue management strategies. However, in general tillage, through direct physical disruption as well as habitat destruction, strongly reduces macro-fauna including both litter transformers and ecosystem engineers. The above outlined evidence for the improved soil quality and production sustainability with well implemented CA systems is clear, although research remains inconclusive on some points. At the same time, the evidence for the degradation caused by tillage systems is convincing especially in tropical and sub-tropical conditions and for biological and physical soil quality. Therefore, even though we do not know how to manage functional CA systems under all conditions, the underlying principles of CA should provide the foundation upon which the development of new practices is based, rather than be considered a parallel option to mainstream research activities that focus on improving the current tillage-based production systems under diverse soil as well as ecological conditions. 


\section{Introduction}

Tillage is age old, fundamental agro-technical operation, performed to make soil environment favourable for crop growth and development. Through, tillage sometimes can lead to soil degradation resulted into development of compacted soil having low SOC and restricted drainage. CT practices being highly intensive in nature, their continual use for crop production may account for higher labour and fuel cost resulting in lower economic returns to the growers pushing them into perpetual trap of poverty (Jat et al., 2012). Moreover, CT along with faulty agricultural practices such as deforestation, poor rangeland management, selection of incongruous crop sequences and burning of crop residues etc, directly and indirectly reported to be associated with wide variety of agricultural challenges such as water and labour crises, extended land degradation, poor soil fertility and agricultural related climate change which put larger pressure on available agricultural land in order to feed out the ever increasing human and animal population (Stocking and Murnaghan, 2001). Therefore, under current scenario, there is an urgent need to identify, demonstrate and to recommend tillage practices which are alternate to $\mathrm{CT}$ systems and can address the above mentioned challenges, so that agriculture may emerge as a source of farmers' prosperity. CT practices, particularly under fragile agro-ecosystems, was interrogated first time in the 1930s, when wide areas of United States was devastated due to dustbowls that produced as a result of intensive tillage over this region. This put larger force on US government and as a result the alternative tillage practices to CT systems which mainly involved reduced ion in tillage intensity and residue retention over the surface soil were developed and the term CA was introduced to cover such practices. In 1940s the concept and principles of CA were described in detail by Edward Faulkner in his book "Ploughman's Folly". In 1990s CA spread exponentially, leading to a revolution as a result today it is practising over $156 \mathrm{M}$ ha area worldwide. Though, CA is still far from being over as the creativity of farmers and researchers and we needs more and more improvements to get the full benefits of the system for the soil, environment and the farmers.

CA involves soil management practices that include (1) planting of crops with minimum soil disturbance (2) maintenance of permanent soil cover and (3) diversified crop rotations that improve soil's bio-physico-chemical behaviour, thereby helped us in arresting the land degradation and water pollutions associated with CT practices (Sharma and Behera, 2009). CA include a range of tillage practices i.e. no-tillage, direct-drilling, minimum tillage, ridge tillage that eliminate and/or reduce intensity of tillage operations and aims at retention of maximum crop residue over the soil surface that served as physical berrier against soil erosion (Baker $e t$ $a l ., 2007)$. The beneficial effect of CA reflects not only in terms of increased crop productivity and labour saving but it also helps in achieving environmental sustainability beside soil and land regeneration.

CA has been reported to improving crop input-output relationship, conserving natural resources through lowering soil erosion, arresting water losses through reducing soil evaporation, sequestering atmospheric carbon in soil and reducing energy needs of agricultural sector (Jat et al., 2005; Yadav et al., 2016a). Research evidence suggests that adoption of CA in proper way can address the emerging challenges of agricultural sector and conserve/improve the quality of environment. In this review we evaluate the potential of CA to reimbursement the current issues related to soil quality. 


\section{Needs of CA}

According to FAO Terra STAT globally around $6140 \mathrm{M}$ ha area of agricultural land, pasture, forest and woodland had been degraded since mid-twentieth century. The unchecked land degradation has been reported to affected a wide range of cultivated area over throughout the globe i.e. Africa (1222 M ha), Asia (2501 M ha), Australia and pacific (368 M ha), Europe (403 M ha), North America (796 M ha) and South America (851 $\mathrm{M}$ ha). Uncheked soil erosion, intensive cultivation, deforestation, industrialization are indentified as key reasons responsible for massive land degradation. Among them, intensive cultivation of soil is one of the severe force that reported to be cause extended land degradation through wind (semi-arid tropics areas) and water erosion (humid and sub-humid areas) and it also a major force that known to gave birth to CA practices. Land degradation especially through soil erosion accountable for loss of top fertile soil layer along with carbon and other nutrients leading to formation of soil that composed of lower level of soil organic matter and nutrients. Land degradation has also been reported to being accused for water contamination through enrichment of water bodies with various agro-chemicals that can lead to eutrophication (Verheijen et al., 2009). Under natural conditions annual mean soil formation rate is about 300 to $1400 \mathrm{~kg} \mathrm{ha}^{-1}$ while annual mean soil loss through erosion is about 300 to $4000 \mathrm{~kg} \mathrm{ha}^{-1}$ which sometimes under extreme climatic conditions can reach as high as $10000 \mathrm{~kg} \mathrm{ha}^{-1}$ (Bai et al., 2008; Verheijen et al., 2009). Worldwide, soil erosion (water and wind) alone reported to affect around $1643 \mathrm{M}$ ha of total cultivated area out of which $1094 \mathrm{M}$ ha shared by water erosion alone (Lal, 2003). The problem of land degradation through water and wind is more sever in Asia and Africa (sub-tropical world) where its reported to affect nearly 407 and $267 \mathrm{M}$ ha of cultivated area, respectively (Lal, 2003). Soil erosion directly or indirectly linked with some issues related to agricultural soils e.g. loss of top fertile soil, poor soil organic matter status, lower potential for carbon sequestration, larger emission of greenhouse gases (GHG) and enhanced climate change forcing farmers to find out alternate source for their livelihood (Reicosky, 2001). Worldwide, agricultural and its allied activities are well known agents for climatic variability through emission of various GHG to the atmosphere, especially carbon dioxide $\left(\mathrm{CO}_{2}\right)$. CT practices has been reported to associate with lower SOC level due to its higher oxidation which leads to emission of $\mathrm{CO}_{2}$ to the atmosphere that ultimately leads to climate disruption (Basch et al., 2012). Usually, large energy required for crop establishment through CT practices which further makes its crucial mean of $\mathrm{CO}_{2}$ emissions from agricultural sector (Reicosky and Archer, 2007). Under current scenario, to achieve the goal of agricultural sustainability and intensification, there is an urgent need to resolve the above discussed issues associated with intensive crop production. For this purpose, some agronomic management practices e.g. CA practices has been extensively evaluated, demonstrated and found potential alternative to $\mathrm{CT}$ and shows great prospective to mitigate these emerging challenges. CA is grounded on the principles of soil rejuvenation, envisioned to maximizing the use efficiency of agricultural inputs e.g. seed, nutrient, water, energy and labour leading to higher profits to the grower (Dumanski et al., 2006). The goals of CA are to optimizing the crop productivity and farm income through maximum use of available resources and their effective recycling in the agro ecosystem while arresting the adverse impacts on environment (Jat et al., 2012). It has been widely tested and demonstrated that long term application of CA resulted in better water quality, provided excellent soil erosion 
control, and lowered the GHG emissions associated with agriculture production (Kassam et al., 2012).

\section{Present status of CA}

The worldwide quantification of CA area is tricky because the statistics on specific CA practices except $\mathrm{ZT}$ is not documented. Usually, the area under ZT is used as a proxy for CA (Hobbs and Govaerts, 2010). At present, ZT occupied around $156 \mathrm{M}$ ha worldwide, increasing with the pace of $7 \mathrm{M}$ ha annually (FAO, 2016). Globally, USA (35 M ha), Brazil (31.8 M ha), Argentina (29 M ha), Canada (18.3 M ha) and Australia (17.6 $\mathrm{M}$ ha) are five pioneer countries in adoption of CA practices (Table 1). The area under CA has been significant especially in South America, Argentina, Brazil, Paraguay and Uruguay are using the system on about $70 \%$ of the total cultivated area.

Table.1 Area under CA in different countries of the world: The area with $>30 \%$ ground cover qualified for CA (1000 ha) as per FAO, (2016)

\begin{tabular}{|l|l|l|l|l|l|}
\hline S.No & Country & CA area (1000 ha) & S.No & Country & CA area (1000 ha) \\
\hline 1 & Argentina & $29181(2013)$ & 28 & Malawi & $65(2013)$ \\
\hline 2 & Australia & $17695(2014)$ & 29 & Mexico & $41(2011)$ \\
\hline 3 & Azerbaijan & $1.3(2013)$ & 30 & Morocco & $4(2008)$ \\
\hline 4 & Belgium & $0.268(2013)$ & 31 & Mozambique & $152(2011)$ \\
\hline 5 & Bolivia & $706(2007)$ & 32 & Namibia & $0.34(2011)$ \\
\hline 6 & Brazil & $31811(2012)$ & 33 & Netherlands & $0.5(2011)$ \\
\hline 7 & Canada & $18313(2013)$ & 34 & New Zealand & $162(2008)$ \\
\hline 8 & Chile & $180(2008)$ & 35 & Paraguay & $3000(2013)$ \\
\hline 9 & China & $6670(2013)$ & 36 & Portugal & $32(2013)$ \\
\hline 10 & Colombia & $127(2011)$ & 37 & Moldova & $40(2011)$ \\
\hline 11 & Korea & $23(2011)$ & 38 & Russia & $4500(2011)$ \\
\hline 12 & Finland & $200(2013)$ & 39 & Slovakia & $35(2013)$ \\
\hline 13 & France & $200(2013)$ & 40 & South Africa & $368(2008)$ \\
\hline 14 & Germany & $200(2013)$ & 41 & Spain & $792(2013)$ \\
\hline 15 & Ghana & $30(2008)$ & 42 & Switzerland & $17(2013)$ \\
\hline 16 & Greece & $24(2013)$ & 43 & Syrian Arab & $30(2012)$ \\
\hline 17 & Hungary & $5(2013)$ & 44 & Tunisia & $8(2008)$ \\
\hline 18 & India & $1500(2013)$ & 45 & Turkey & $45(2013)$ \\
\hline 19 & Iraq & $15(2012)$ & 46 & Ukraine & $700(2013)$ \\
\hline 20 & Ireland & $0.2(2013)$ & 47 & UK & $150(2011)$ \\
\hline 21 & Italy & $380(2013)$ & 48 & Tanzania & $25(2011)$ \\
\hline 22 & Kazakhstan & $2000(2013)$ & 49 & USA & $35613(2009)$ \\
\hline 23 & Kenya & $33.1(2011)$ & 50 & Uruguay & $1072(2013)$ \\
\hline 24 & Kyrgyzstan & $0.7(2013)$ & 51 & Uzbekistan & $2.45(2013)$ \\
\hline 25 & Lebanon & $1.2(2011)$ & 52 & Venezuela & $300(2005)$ \\
\hline 26 & Lesotho & $2(2011)$ & 53 & Zambia & $200(2011)$ \\
\hline 27 & Madagascar & $6(2011)$ & 54 & Zimbabwe & $332(2013)$ \\
\hline & Worldwide & & 156991 & \\
\hline & & & & \\
\hline
\end{tabular}


About $45 \%$ of the total area under CA is in South America, $32 \%$ in the Northern America, $14 \%$ in Australia and New Zealand $4 \%$ in Asia and 5\% in the rest of the world including Europe and Africa. It seems that European and African countries are still considered as the developing continents in terms of CA adoption. However, due to hard and long lasting research effort of some governmental and private agencies of Europe and Africa i.e. NEPAD (New Partnership for Africa's Development), EC (European Commission), ECAF (European Conservation Agriculture Federation) and ACT (African Conservation Tillage), CA shows significant increment in rate of adoption in recent years. The area under CA is on the increase in all parts of Asia, and large areas of agricultural land are expected to switch to $\mathrm{CA}$ in the coming decade in China, Kazakhstan, and most likely in India. In South Asia, the concerted efforts over the past decade of Rice-Wheat Consortium for the IndoGangetic Plains (IGP), in countries like Bangladesh, India, Nepal, and Pakistan, now CA practices gaining importance mainly in intensively cultivated irrigated cropping systems. In the rice-wheat cropping system of South-Asia, wheat area under ZT has increased rapidly (Rice-Wheat Consortium, 2006). In India, the CA practices has been extensively tested through the combined efforts of several State Agricultural Universities, Indian Council of Agricultural Research (ICAR) institutes and the CGIAR system promoted Rice-Wheat Consortium on adaption, promotion and development of these practices resulted that now these technologies are finding rapid acceptance by the farmers and covering nearly $2 \mathrm{M}$ ha area under rice-wheat system in IGP belt (Haryana, Punjab and Western Uttar Pradesh). Long term adoption of CA practices has been reported to increase the factor productivity and crop yields, enhanced agricultural sustainability, provided better income to the growers, ensure timeliness of cropping practices, reduction in drudgery, and improved ecosystem services which leads to diverse pattern of productivity, economic, social and environmental benefits from CA technologies. However, technical and financial support from governments, donor agencies and international organizations for $\mathrm{CA}$ research and development word wide has increased the adoption and uptake of $\mathrm{CA}$ in various countries which is expected to accelerate in the coming years under $\mathrm{CA}$ in recent years (FAO, 2013).

\section{Concept of soil quality}

Soil quality is one of the basic and fundamental indicators to access the feasibility of any crop management practice for sustainability. As better soil quality helps in maintaining sustainability of crop production system by conserving resource base, optimizing soil conditions and reducing food production vulnerability. Soil quality refers to the goodness of soil, to function within its natural ecosystem boundaries, to sustain agricultural productivity. It also maintains or enhances water and air quality, and support human health and habitation (Arshad and Martin, 2002). Soil health can also be defined as the constant capability of soil to work as a essential commodity for all living system, within particular ecosystem and land-use boundaries, to sustain biological productivity, maintain or enhance the quality of air and water, and promote plant, animal and human health (Doran and Zeiss, 2000). The use of term soil health has also emerged in recent years, as variation in ability of soils to suppress plant diseases is known since many decades (Janvier et al., 2007). Van Bruggen and Semenov, 2000 viewed soil health as a dimension of ecosystem health and explained soil health as the resistance and resilience of soil in response to various stresses and disturbances. Thus, there is a 
considerable degree of overlap in the meaning of soil quality and soil health (Doran, 2002). Soil health perceptions tend to focus more on biotic components of soil (Anderson, 2003). Likewise term soil quality is related with soil degradation or deterioration in soil health or quality implies loss of the vital functions of soil viz. providing physical support, water and essential nutrients required for growth of terrestrial plants, regulation of the flow of water in the environment and elimination of the harmful effects of contaminants by means of physical, chemical and biological processes (Constanza et al., 1992). Soil quality has long been considered as important component of agricultural sustainability and treated as conceptual transformation of the concept of sustainability to be soil system restoration. Within the system of agricultural production, better soil quality related to the capacity of the soil to regulate a high productivity without any kind degradation in soil and environment. Soil quality can be accessed on the basis of physical, chemical and biological characteristics of the soil. With respect to biological soil quality, a high quality soil can be considered a 'healthy' soil. Management factors viz. tillage, residue management and crop rotations can modify soil physical, chemical and biological quality (Karlen et al., 1994). A comparative soil quality evaluation is one in which the performance of the system is determined in relation to alternatives. This assessment is useful for determining differences in soil attributes among management practices that have been in place for some period of time (Wienhold et al., 2004). The conclusion of aforesaid discussion suggests that the quality and health parameters of soil determine agricultural sustainability and environmental quality, which jointly determine plant, animal and human health (Doran, 2002). The alteration in management practices over long period of time can alter these physical, chemical and biological soil quality parameters and hence considerably affect the agricultural system productivity. So, it is needful that a dynamic assessment is necessary for determining the direction and magnitude of change in a management practice (Wienhold et al., 2004), especially when compared to the common, existing farmer practices and it must be understood that this assessment normally must involve an adequate time frame.

\section{CA and soil quality}

\section{Soil physical quality}

Studies reveal that adoption of CA practices leads to significant improvement in soil physical environment and thereby soil quality over time (Lal, 2005; Verhulst et al., 2010). However, effects of CA on soil physical properties can vary from location to location depend on the tillage system and their intensity, agro-climatic condition and type of soil. For example, ZT systems which maintain residue retention over soil surface resulted in significant change in soil physical environment, especially in upper few centimetre of the soil (Anikwe and Ubochi, 2007). The beneficial effect of CA in term of better soil quality is reflects through improvement in physical soil properties like lower bulk density (BD), higher aggregate stability, enhanced water holding capacity and better soil structure.

\section{Soil structure and aggregation}

Among the physical factors, soil structure is one of the most important parameter that have strong correlation with soil quality and most often used to test the suitability of different tillage practices for crop production. In general, the degree of stability of aggregates is treated as sinonomious with soil structure (Bronick and Lal, 2005). Usually, soil structure stability is refer to the ability of aggregates to remain intact when exposed to 
different biotic and abiotic stresses while soil aggregation is a dynamic process that depends on various agents such as soil fauna, roots, inorganic binding agents and environmental variable (Six et al., 2004; Kay and Vanden Bygaart, 2002) and measures of aggregate stability are useful means for assessing soil structural stability. Soil Aggregation and their stability have great influences on water holding capacity, nutrient dynamics as well as on soil tilth (Hillel, 2004). Therefore, aggregated soil structure is most desirable characteristics for higher crop productivity. Soil management practices such as tillage can influence the quantity and persistence of binding agents, which may lead to aggregate formation or breakdown depends on tillage system chosen. Therefore, soil aggregation and structural stability can be used to evaluate agricultural management practices and select those that optimize crop growth and minimize soil and nutrient loss. Many studies shows that CA practices have been associated with higher stable aggregates in the surface soil than $\mathrm{CT}$ and this correspondingly results in high total porosity under CA. Intensive tillage in case of CT disrupts soil aggregates, fragments root and mycorrhizal hyphae, which are act as major binding agents for micro-aggregates leading to lower soil aggregation and structural stability in CT over CA (Wang et al., 2015). Moreover, residue removal besides intensive disturbance in CT may also leads to interruption of different aggregate formation process over time (Six et al., 2001). The intensive disruption of soil aggregates attributed to redistribution of the SOM which can influence the stability of macro-aggregates. In contrast, greater soil macro-aggregation due to reduced soil disturbance and maintenance of residue cover is important reason for higher aggregate stability with CA practices (Filho et al., 2002). For example, Parihar et al. 2016 reported that continuous adoption of $\mathrm{CA}$ practices i.e. ZT and Permanent bed (PB) along with residue retention over seven year resulted into 23 to $32.5 \%$ higher water stable aggregates, 47.1 to $53.4 \%$ higher mean weight diameter and 28.5 to $33.9 \%$ higher geometric mean diameter compared to $\mathrm{CT}$ in $0-15 \mathrm{~cm}$ soil depth, respectively. The lesser soil disturbance under CA practices reduces oxidation of SOC and hence improves storage of SOC, microbial diversity to the soil which enhances above listed physical soil parameters (Gathala et al., 2011; Jat et al., 2013; Limon-Ortega et al., 2002). Likewise, Bhattacharya et al. 2013 reported that continuous adoption ZT for 4 years at the fixed site had a greater proportion of large macroaggregates and mean weight diameter and their stability than $\mathrm{CT}$ in $0-5 \mathrm{~cm}$ soil depth. The intensive mechanical disruption of macroaggregates of soil which might have exposed previously protected SOC against oxidation leads to decline in aggregates size in CT (Pinheiro et al., 2004; Kumari et al., 2011). However, ZT promoted macroaggregation, especially within the surface soil layer because of residue retention and less disruption of aggregates. The beneficial effects of $\mathrm{ZT}$ in term of better structural stability may also be partly due to higher activity of soil microbes such as earthworms and higher microbial biomass than in CT (Nyamadzawo et al., 2009). It has been widely reported that SOC have major role in aggregation and their stability, the retention of residue of previous crop over soil surface leads to buildup of SOC thus, improve soil structure and aggregation stability (Marcolan et al., 2007; Madari et al., 2005; Wright and Hons, 2005).

Crop residues received from previous crop has been reported to be associated with development of new soil aggregates through facilitating formation of nucleation centre which is essential for the formation of new aggregates by accelerating the pace of microbial activity at the point where these soil 
aggregates are developed (De Gryze et al., 2005). Govaerts et al. 2007 reported that the mean weight diameter and stability of soil aggregates was significantly higher with residue retention and decreased with decreasing amounts of residues under rainfed PB planting system at subtropical highlands of Mexico. Similarly, Wang et al. 2015 from China, also reported the beneficial effect of residue management under semi-arid climate where the practice of residue retention significantly increased mean weight diameter and stability of soil aggregates in the magnitude of $16.1-40.3 \%, 10.1-36.0 \%, 11.0$ $36.3 \%$ compared to residue removal in $0-10$, 10-20, 20-30 cm soil depth, respectively. Similar outcome were obtained by LimonOrtega et al. 2006, while working in an irrigated system, where the soil aggregates obtained from PB system showed higher rate of dispersion with residue removal while lowest where all residue was retained over the soil surface. In $\mathrm{CA}$, the practice of residue retention over soil surface has not only reported to accelerate the pace of aggregate formation, but also known to act as strong binding agent therefore reduce the breakdown of aggregates by arresting the problem of soil erosion by protecting them against raindrop impact.

Cropping systems are often known to have strong influence over soil aggregation and their stability. Altering crop rotation can influence SOC by changing quantity and quality of organic matter input (Govaerts et al., 2009) and thus indirectly has the potential to alter soil aggregation. For example, inclusion of legumes in crop rotations can influence soil aggregation and their stability because of the higher binding capacity of their fine roots as well as organic substances that released from legumes roots are known to contribute to the formation of new soil aggregate (Hillel, 2004). Numerous studies proved that ZT, with inclusion of legume crops and/or retention of legume residue under intensive crop rotations can increase SOC, improve aggregation as well as their stability, and preserve the nutrients for plant and soil micro-organisms (Jacobs et al., 2009). For example, Raimbault and Vyn, 1991 reported that inclusion of legume under maize based intensive rotations had higher proportion of fine aggregates as well as and soil aggregate stability. Similar results also reported by Bissonette et al., 2001 with inclusion of mungbean in barley-maize rotation that resulted into $6.7 \%$ higher mean weight diameter of soil aggregates in mouldboard ploughing system and $33.3 \%$ in chisel ploughing system, compared to the maize monoculture. However, an another study shows positive effect of the incorporation of legume residues by tillage rather than leaving them on the soil surface, which could result in better contact between soil particles and soil microbes in maize-wheat cropping system (Christopher et al., 2009; Zhao et al., 2012). In, Parihar et al., 2016 reported that inclusion of chickpea and mungbean in intensive maize based rotation attributed significantly higher water stable aggregates, mean weight diameters and geometric mean diameter compared to continual maize and maize succeeding by mustard in rotations under north-western Indo-Gangetic-Plains (IGP) of India. These finding of higher water stable aggregates with inclusion of legume in intensive crop rotations are in close agreement with Six et al., 2002 and Biswas et al., 2009. Inclusion of legumes in intensive maize based rotation might result in higher SOC due to faster and easier decomposition of lower $\mathrm{C}$ : $\mathrm{N}$ ratio legume residues and root nodules which ultimately favour higher physical soil quality. The similar relationships of SOC with soil aggregation properties were also reported by several other researchers elsewhere (Srinivasarao et al., 2013; Filho et al., 2002; Six et al., 2002; Pinheiro et al., 2004). Thus enhancement in SOC content is important for better soil aggregation. 


\section{Hydraulic conductivity}

Hydraulic behavior of the soil was found to be significantly and positively correlated with the total soil macro-pores and tillage practices has potential to alter macro-pores of the soil by affecting setting and consolidation of soil particles over time (Rasse et al., 2000). Hydraulic conductivity would be expected to be higher in ZT compared to CT due to the larger macropore conductivity as a result of the increased number of biopores (Eynard $e t$ al., 2004; McGarry et al., 2000). However, the reported outcomes are mix in nature which might be partly due to difficulty in measuring hydraulic conductivity under presence of residue cover over the surface in $\mathrm{ZT}$ that interfere with measurement instruments or the removal of undisturbed samples and cores that may attribute high variation in values of hydraulic properties of the soil (Strudley et al., 2008). Moreover, the depth of soil sampling, soil texture, gradient of soil, tillage system and amount of residue retention are also known to create large differences in soil hydraulic conductivity and water-holding capacity (Blanco-Canqui et al., 2006). Many researchers have found that ZT significantly improved saturated and unsaturated hydraulic conductivity owing to either continuity of pores or flow of water through very few large pores (Bhattacharya et al. 2006). Greater number of macro-pores, little soil disturbance to soil and presence of litter of well decomposed residues formed by accumulated organic matter is main cause of better hydraulic conductivity under CA practice over CT (McGarry et al., 2000; Osunbitan et al., 2005). Likewise, Kahlon et al., 2013 and Chen et al. 2014 found that reduced tillage significantly increased the initial soil infiltration capacity over $\mathrm{CT}$ which resulted in higher saturated and unsaturated hydraulic conductivity of the soil as compared to CA. Parihar et al. 2016 reported, that after seven year of adoption the saturated conductivity of the a sandy loam soil increased by 14.3 and $11.2 \%$ in PB planting and 11.1 and $12.0 \%$ in ZT in $0-15$ and $15-30$ $\mathrm{cm}$ soil layers, respectively, compared to CT in north western IGP of India. The increase in saturated conductivity under PB and ZT was mainly attributed to decrease in $\mathrm{BD}$ and increase in effective pore volume (Rasool $e t$ al., 2007; Li et al., 2011) due to better soil aggregation.

Singh and Malhi, 2006 reported that after six years of adoption of different tillage and residue management practices over two different soil texture i.e. Black Chernozem and a Gray Luvisol at Alberta, Canada, the saturated hydraulic conductivity of Black Chernozem was significantly lower (33\%) under ZT than under rotovetor tillage. However, the practice of residue retention improved saturated hydraulic conductivity of Black Chernozem soil in both ZT and rototillage system while, the steady-state infiltration rate of Gray Luvisol, was not significantly affected by tillage and residue management. The exact quantification regarding impact of residue management on hydraulic conductivity of soil is very tricky task, largely because of the difficulty in measuring hydraulic conductivity when residue is present over the soil surface. The residue present over the soil surface may cause variation in soil hydraulic conductivity in two ways either by interfering with installation of measurement instruments or by causing obstacles in the removal of undisturbed samples and cores. In general the practice of residue retention in combination with ZT or independently reported to improved soil hydraulic behaviour over time. The positive effects of residue retention on soil hydraulic conductivity are largely due to the production and preservation of greater number of macropores by undisturbed root channels, decaying organics in upper soil surface as well as subsurface, and presence 
passageways of soil microbes such as earthworm and faunal. The diversified crop rotations also significantly affected the saturated conductivity and it increased by 9.3 and $5.9 \%$ with inclusion of legumes in maize based intensive rotations compared to monoculture. The lowest hydraulic conductivity under maize monoculture may be due to higher BD and lower aggregate stability compared legume inclusion.

\section{Soil bulk density}

The beneficial effect of CA based tillage and residue management in terms of lower bulk density is more subjected to the topsoil (0-15 cm) (D'Haene et al., 2008; Gál et al., 2007; Thomas et al., 2007). Continuous adoption of CT may be lead to formation of plough pan underneath the furrow slice, attributed to higher BD in this horizon in tilled situations compared to CA (Hernanz et al., 2002; Dolan et al., 2006). Reduction in intensity of tillage operations through adoption of CA practices would be expected to result in a progressive reduction in soil compaction over time (Kay and Vanden Bygaart, 2002). It has been reported that long term application of $\mathrm{CA}$ practices associated with lower soil $\mathrm{BD}$ and penetration resistance. More aggregated and friable soil due residue retention and minimum soil disturbance of soil leading to lower compaction which accounted for lower soil BD under CA compared to CT (Jat et al.,2013;Obalum and Obi 2010; BlancoCanqui et al., 2006). For example, after longterm adoption tillage practices (24 years) the soil BD was $28.2 \%$ higher in CT than ZT (Utomo et al., 2013). Parihar et al., 2016 reported that after adoption of $\mathrm{CA}$ practices for seven years, the soil BD lowered by 4.3 to $6.9 \%$ in $0-30 \mathrm{~cm}$ soil profile than $\mathrm{CT}$. The decrease in soil BD under CA could be due to higher SOC, better aggregation, increased root growth and biomass (Salem et al., 2015). Further, inclusion of legumes in intensive maize based rotations resulted into significantly lower soil BD compared to monoculture of maize. The higher SOC and differential chemical composition of crop residues and root biomass brings out differential addition of SOC (Congreves et $a l ., 2015)$ that leads to difference in soil BD. The similar findings of lower BD due to pulses inclusion were also reported by Verhulst et al. 2011 and Thierfelder et al. 2012. After 7 years of adoption, the soil PR decreased by 15.9 to $27.1 \%$ in ZT and 15.8 to $30.7 \%$ in PB compared to CT in $0-50 \mathrm{~cm}$ soil depth. The compaction caused through development of plough pan and higher BD under CT practices enhances the soil resistance which might contribute to higher soil PR in repeated tilled soil (Saha et al., 2010). Similar to tillage practices, inclusion of legumes in intensive maize based rotations resulted into significantly lower soil PR compared to monoculture of maize (Parihar et al., 2016). Unger and Jones, 1998 also reported that the PR differed due to crop rotations, being lower for continuous wheat (1.79 $\mathrm{MPa}$ ) than for wheat-fallow (2.32 $\mathrm{MPa}$ ) or wheat-sorghum-fallow (2.42 $\mathrm{MPa})$. Residue retention had a significant impact on soil BD in the in upper soil surface $(0-10 \mathrm{~cm})$ while the difference at deeper soil depth (10$20 \mathrm{~cm}) \mathrm{cm}$ were not found significant (Blanco-Canqui and Lal, 2008). Annual application of rice straw reduced the soil BD by $58 \%$ in $0-3 \mathrm{~cm}$ and $36 \%$ in $3-10 \mathrm{~cm}$ soil depth as compare to unmulched treatment. Likewise, Lal, 2000 found that application rice straw decreased soil $\mathrm{BD}$ from 1.20 to $0.98 \mathrm{Mg} \mathrm{m}^{-3}$ in the $0-5 \mathrm{~cm}$ layer on a sandy loam. Similar results were also reported by Blanco-Canqui et al., 2006.

\section{CA and soil chemical quality}

\section{Soil organic carbon}

Declining fertility status of cultivated lands due to declining level of SOC is a major 
anxiety especially in Asian and African countries left their soils with lower crop productivity and resource use efficiency. SOC being keystone to soil quality also reported to an important indicator of agricultural sustainability. Restoring SOC is important not only to achieve food security and soil quality but also to offset the negative impact of agricultural related climate change (Lal, 2004). Many researchers claimed that intensive tillage practices increases oxidation of SOC although the rate is climate and soil dependent, leading to lower SOC content over time. The loss of SOC can be ameliorated or minimized through long term adoption of CA practices that reduces its oxidation by causing less mixing of the soil. Another reason for accumulation of SOC under CA is presence of residue mulching which act as physical cover against soil erosion. Therefore, one would expect a substantial enrichment of SOC under CA compared to CT, especially in soils with relatively low initial organic matter status (Halvorson et al., 2002). Among the CA practices, over last three decades, ZT have been intensively tested, applied and demonstrated in order to maintain or improve the stock of organic carbon in soil and reduce $\mathrm{CO}_{2}$ emissions (Dimassi et al., 2014). A comparative analysis of SOC under different medium and long term studies revealed that ZT accounted higher SOC in the tune of 3.86$31.0 \%$ over conventional tillage (Balota et al., 2004; Govaerts et al., 2009). They also suggested that to achieve the beneficial effect of ZT in terms of higher SOC, its long term implementation is essential. Likewise, Machado et al. 2001 found that adoption of ZT resulted into significant increase in total carbon (30\%), active carbon pool (10\%), and passive carbon pool (18\%) compared to CT (Aziz et al. 2015). The higher SOC under ZT might be due to increased soil aggregation that can store more carbon over CT. Thus, ZT is recognized as promising strategy to maintain or even improve SOC stocks in soil
(Bayer et al., 2000). Adoption of CA practices (PB and $\mathrm{ZT}$ ) over long run (7 years) recorded significant higher SOC (23.6 to 35.3 $\%$ ) than the CT under $0-15 \mathrm{~cm}$ (Parihar et al., 2016). The intensive tillage in case of CT increased organic matter decomposition and enhanced its oxidation (Balasdent et al., 2001; Balota et al., 2003; Thomas et al., 2007) that leads to lower SOC under CT compared to CA. In contrast, the crop roots remain intact in the root zone due to non-disturbance of the soil under $\mathrm{CA}$ practices (PB and ZT) which might facilitate enhancement of SOC through their decay. The enhancements in SOC due to CA practices were also reported by Baker et al., 2007; Thomas et al., 2007 and Kaiser et al., 2014.

Usually, SOC changes proportionally to the amount of crop residues returned to the soil, agronomic management practices that influence yield and affect the residues returned to soil are likely to influence SOC (Campbell et al., 2000). Returning more crop residues associated with an increase in SOC concentration of the soil (Wilhelm et al., 2004). Some studies suggested that apart from tillage system chosen, crop rotations also known to have significant positive impact on SOC. For example, Amado et al., 2001 reported significantly more SOC when leguminous cover crops added to the rotation in conjugation with ZT. Besides enriching with SOC, legumes also added a substantial quantity of $\mathrm{N}$ to the soil, which results in increased biomass production of the succeeding crops (Bayer et al., 2000). Long term inclusion of legumes in intensive maize based rotations resulted into 18.9 and $20.4 \%$ higher SOC in 0-30 cm soil depth compared to monoculture of maize (Parihar et al., 2016). This might be due to differences in quantity and chemical composition of crop residue biomass and/or root exudates among the residues of cereals and legumes (Congreves et al., 2015). Further, the lower 
$\mathrm{C}: \mathrm{N}$ ratio of legume residue caused rapid decomposition and hence attributed to higher SOC compared to monoculture of maize. The results of some of long-term experiments have suggested that to get the full benefit of ZT in terms of higher it should be used in conjugation legume in crop rotations (Bolliger et al., 2006). Crop rotation with legume component and ZT tends to build up of SOC in the soil (Greenland and Adams 1992). For example, Calegari et al. 2008 found that no tillage with winter cover crops resulted in the greatest SOC content, most closely to native undisturbed forest. Thierfelder et al. 2015 found $31 \%$ greater SOC with inclusion of cowpea and sun hemp in maize based crop rotations. Saha and Ghosh, 2013 also reported the positive effects of legume residue application in cereal cropping systems on soil carbon content.

Formation of higher soil micro-aggregates under CA is considered as major mechanism of carbon sequestration in soil (Six et al., 2000). Carbon sequestration accountable when net addition of SOC through crop residues exceeds carbon removal in term of crop harvest harvested, microbial respiration, carbon emissions from fuel and the manufacture of chemical fertilizers, etc.). To achieve positive carbon stock in the soil, we must need to either increased carbon inputs to the soil, decreased oxidation of SOC, or a combination of both (Paustian et al., 2000; Follet, 2001). CA as retained a significant portion of crop residue on soil surface rather than mixing into the soil as under CT, facilitate slower decomposition of organic matter on one hand and reduce $\mathrm{CO}_{2}$ emission from the soil on other leading to net fixation or sequestration of carbon in the soil (Bot and Benites, 2005).

\section{Nutrient dynamics}

Tillage, residue management and crop rotation can strongly affect the nutrient dynamics of any soil through their effect on mineralization and recycling of soil nutrients (Galantini et al., 2000). It is believed that long-term adoption of CA practices can lead to higher buildup of nutrients in top soil due to larger nutrient mineralization potential of soil as compared to CT (Rasmussen 1999; Duiker and Beegle, 2006). The benificial effect of CA in terms of higher nutrient availability partly may be due to crop residues retention over soil surface in comparison with incorporation of crop residues with CT (Ismail et al., 1994) and partly due to arresting their leaching losses by reducing decomposition of surface placed residues (Balota et al., 2004; Kushwaha et al., 2000). However, the response of soil chemical fertility to different tillage practices is reported to be varying with location to location, soil type, cropping systems, climate, fertilizer and other agronomic management practices (Rahman et al., 2008).

Effects of CA on soil nitrogen $(\mathrm{N})$ content usually in line with those observed for SOC, as the $\mathrm{N}$ cycle is inextricably linked to the carbon cycle (Bradford and Peterson, 2000). Intensive tillage reported to increases disruption of soil structure, making SOC more accessible to soil microbes (Six et al., 2002, Beare et al., 1994) and increasing mineralization of $\mathrm{N}$ from active and physically protected $\mathrm{N}$ pools (Christensen $e t$ al., 2000). Higher amount of stable microaggregates and increased levels of physical protection of carbon as well as $\mathrm{N}$ were repoted under PB planting compared to CT (Lichter et al. 2008).

Govaerts et al. 2006 found that after long term adoption of CA (26 cropping seasons) in an input responsive well irrigated production system, the $\mathrm{N}$ mineralization was higher in $\mathrm{PB}$ with residue retention than in $\mathrm{CT}$ with residues incorporation. $\mathrm{ZT}$ with residue retention over long run can enhances the supplying power of soil that leads to higher 
soil available $\mathrm{N}$ as compared to $\mathrm{CT}$. The composition ( $\mathrm{C}: \mathrm{N}$, lignin, polyphenols and soluble $\mathrm{C}$ content) of residues will affect their decomposition as the $\mathrm{CN}$ ratio together with initial $\mathrm{N}$, lignin, and polyphenols is one of the most often used criteria for residue quality and its rate of decomposition (Hadas et al., 2004; Nicolardot et al. 2001).

During the decomposition of organic matter, inorganic $\mathrm{N}$ can be immobilized (Zagal and Persson, 1994), especially when organic material with a large $\mathrm{CN}$ ratio is added to the soil. $\mathrm{N}$ immobilization can occur as a consequence of cereal residue retention, especially during first few years of implementation of CA (Erenstein, 2002). Many literature advocate that CA practices associated with lower level of soil $\mathrm{N}$ because of greater immobilization by the residues left on the soil surface (Bradford and Peterson, 2000). This temporary but higher immobilization of $\mathrm{N}$ under $\mathrm{CA}$ reduces $\mathrm{N}$ losses by reducing the chance of leaching and denitrification of mineral $\mathrm{N}$ (Follet and Schimel, 1989).

Numerous studies also showed P stratification in soil under different tillage systems where ZT system associated with higher concentration of $\mathrm{P}$ due to preferential movement of $\mathrm{P}$ in the soil (Abdi et al., 2014). Moreover, the shallower incorporation of crop residues and fertilizer $\mathrm{P}$ as well as small $\mathrm{P}$ losses due to water erosion under CA leads to higher $\mathrm{P}$ contents in the surface soil. Piegholdt et al. 2013 also reported 15\% higher total $\mathrm{P}$ content in the top soil $(0-5 \mathrm{~cm})$ of ZT plots as compared to CT due to larger $\mathrm{P}$ addition from decomposition of residues retained on the soil surface. Likewise, higher $\mathrm{P}$ levels in ZT than in CT were reported by other researchers (Du Preez et al., 2001; Duiker and Beegle, 2006). The higher values of available $\mathrm{P}$ under CA practices largely due to reduced mixing of the fertilizer $P$ with the soil, leading to lower P-fixation. This is a benefit when $\mathrm{P}$ is a limiting nutrient, but may be a threat when $P$ is an environmental problem because of the possibility of soluble $\mathrm{P}$ losses in runoff water (Duiker and Beegle, 2006). Franzluebbers et al., 1995 suggested that adoption of ZT leads to redistribution of $\mathrm{P}$ compared CT because of direct result of surface placement of crop residues that leads to accumulation of SOC and microbial biomass near the surface. Franzluebbers and Hons, 1996 and De Oliveira and Pavan, 1996 also observed higher P levels, probably due to the accumulation of $\mathrm{P}$ in soil and the higher SOC content of the soil. Roldan et al., 2007 reported that available $\mathrm{P}$ was not affected by tillage system and crop rotations.

CA practices can conserves and increases availability of $\mathrm{K}$, near the soil surface where crop roots proliferate (Franzluebbers and Hons, 1996). According to Govaerts et al., 2007 PB had 1.65 and 1.43 times higher concentration of $\mathrm{K}$ in the $0-5 \mathrm{~cm}$ and $5-20 \mathrm{~cm}$ respectively, than CT. Ismail et al., 1994 also reported higher extractable $\mathrm{K}$ levels at the soil surface with ZT as tillage intensity decreased. Du Preez et al., 2001 observed increased levels of $\mathrm{K}$ in $\mathrm{ZT}$ compared to $\mathrm{CT}$, but this effect declined with depth. Govaerts et al., 2007 found that the $\mathrm{K}$ concentration in both the $0-5 \mathrm{~cm}$ and $5-20 \mathrm{~cm}$ soil layers increased significantly with increasing residue retention under PB planting compared to CT. No effect of crop rotation on $\mathrm{K}$ concentrations was observed by Roldan et al., 2007. However, Yadav et al., 2016 reported that after seven years of CA the highest amount of N, P and K $\left(219.8,24.9\right.$ and $\left.203.1 \mathrm{~kg} \mathrm{ha}^{-1}\right)$ in $0-15 \mathrm{~cm}$ soil surface was recorded under PB planting while minimum amount of available $\mathrm{N}, \mathrm{P}$ and $\mathrm{K}$ were observed under CT. The recycling of the higher amount crops residue of previous due to higher biomass yield in PB treatments lead to addition of more nutrients compared to CT. While, in case of CT the stover/ straw get 
incorporated in deep soil layer and which leads to rapid decomposition and might also lead to leaching of mineralized nutrients in much deeper soil layers which in turn reduces the available these nutrients in CT. Moreover, the chelating of these nutrients with organic matter in non-disturbed soil leads the improvement of soil nutrient status in different soil depths (Borie et al., 2006; Singh et al., 2014) and thus causes enhancement of soil NPK status. The similar findings of enhancement in available nutrients due to CA practices in soil were also reported by Graham et al., 2002; Borie et al., 2006 and Wang et al., 2008 for N; Malhi et al., 2011 for P and Du Preez et al., 2001 and Govaerts et al., 2007 for K. The enhancement in available NPK status due to ZT and PB practices was also reported by Parihar et al., 2011. Most research reported that tillage practices does not affect extractable $\mathrm{Ca}$ and Mg levels of soil (Govaerts et al., 2007; Duiker and Beegle, 2006) primerily in the condition where CEC is associated with clay particles (Duiker and Beegle, 2006). However, Edwards et al., 1992 found higher extractable $\mathrm{Ca}$ with $\mathrm{CA}$ than $\mathrm{CT}$ due to the higher levels SOC under CA. The $\mathrm{Ca}$ concentrations were higher in the $0-5 \mathrm{~cm}$ layer of ZT than in the deeper layers in the work of Duiker and Beegle, 2006 but the reverse was true for mouldboard tillage. This could be attributable to the tillage after the last lime application (calcitic limestone) in the mouldboard treatment.

Increasing supply to food crops of essential micronutrients might result in significant increases in their concentrations in edible plant products, contributing to consumers' health (Welch, 2002). Micronutrient (Zn, Fe, $\mathrm{Cu}$ and $\mathrm{Mn}$ ) tend to be present in higher levels under ZT with residue retentions compared to CT, especially near the soil surface (Franzluebbers and Hons, 1996). In contrast, Govaerts et al., 2007 reported that tillage practice had no significant effect on the concentration of extractable $\mathrm{Fe}, \mathrm{Mn}$ and $\mathrm{Cu}$, but that the concentration of extractable $\mathrm{Zn}$ was significantly higher in the $0-5 \mathrm{~cm}$ layer of $\mathrm{PB}$ planting compared to $\mathrm{CT}$ with full residue retention. Similar results were reported by $\mathrm{Du}$ Preez et al., 2001 and Franzluebbers and Hons, 1996. Residue retention significantly decreased concentrations of extractable $\mathrm{Mn}$ in the $0-5 \mathrm{~cm}$ layer in PB compared to CT (Govaerts et al., 2007). However, according to Peng et al., 2008, the Mn concentration was higher under CA as compared to $\mathrm{CT}$ due to increased SOC content.

\section{CA and biological soil quality}

Soil being richest source of living organism represents one of the most diversified habitats over earth. It has been estimated that 1 gram of soil contain millions of living organism (bacteria, fungi, mycorrhiza, protozoa, nematodes, earthworms, mites, enchytraeidsants, termites, beetles and spiders etc) (Hawksworth, 1991; Hawksworth and Mound, 1991). Improvement in ecosystem function and services of arable soils through enhancement of microorganism diversity is well known thus the microbial biomass and their functional diversity is used as sensitive indicator to access the soil quality (Médiène et al., 2011). Since, due to exponential increase in global population, the demands for food are likely to increase substantially, the major challenge for present population is to enhance the food production with the use of soil management practices that can maintain soil biodiversity. Intensive cultivation of soil for longer period leads to reduced microbial biodiversity compared to uncultivated soils and/or less disturbed soil. Impact assessment of tillage practices on soil microbial diversity and to understand ecosystem functions and services that are linked with soil microbes is main challenge for development of strategies toward conservation of soil biodiversity of 
agro ecosystem (Brussaard et al., 2007; Giller et al., 2005; Temme and Verburg 2011). In this aspect CA practices were widely tested and have potential to reach the goal of safe productivity conserving or sustaining soil biodiversity (Holland 2004).

The soil organic matter (quantity, quality and its distribution in the soil) is major factor that strongly affect diversity, biomass and activity of soil microorganisms as it is the basic food source for soil biota (Wardle 1995). CA practices such as ZT and reduced tillage systems are known to reduce land degradation through arresting soil erosion and enhance SOC which sustains soil health (Dao, 1993; Woods and Lenne, 1997). Usually, the microbial diversity is negatively correlated with intensity of tillage (Kladivko, 2001; Jinbo et al., 2007). The impact of soil tillage over microbial parameters of soil mostly determined through climate, location and below as well as above environmental conditions. Therefore, one should consider all these factors before choosing tillage practices for crop production. The following sections review implications of soil tillage on soil microorganisms. To assess the impact of soil tillage on soil diversity the microbes of soil soil fauna divides into following groups (A) Microfauna (i.e. Bacteria, Mycorrhiza, Protozoa, Nematods, etc.) (B) Mesofauna (Enchytraeidae, Collembola, Acarina, Protura and Diplura) (C) Macrofauna (Gastropoda, Lumbricidae, Arachnida, Isopoda, Myriapoda, Diptera, Lepidoptera, Coleoptera) (Lavelle 1997).

\section{Microfauna}

Microfauna includes a wider range of soil microbes that mostly engaged in utilizing low molecular weight organic compounds of the soil solution. This class of microorganism plays many important roles in variety of functions soil. Soil tillage, has strong impact on bio-chemical behavior of soil imparted through mechanical manipulation of soil subjected (Hassen et al., 2007). Long term adoption of CA supposed to be enhancing not only the biological activity but also their biomass and diversity compared to CT (Lupwayi et al., 2001). Soil bacteria represent an important group of microbes, their activities and diversity very with soil to soil and tillage practices and crop rotations reported to have strong effect on them, especially, the Rhizobium bacteria that engaged in biological $\mathrm{N}_{2}$ - fixation (Ferreira $e t$ al., 2000). For example, Dogan et al., (2011) reported that adoption of $\mathrm{ZT}$ with residue retention resulted into significantly higher number of effective nodules as compare to CT with burnt residue. The lower value of nodules in CT plots where plant residue was burnt may be due to destruction of Rhizobium bacteria's because of higher temperatures of soil. Moreover, the diversity and activity of Rhizobium bacteria's has been reported to negatively correlate with intensity of soil tillage (Ferriera et al., 2000 and Hassen et al., 2007). Many researchers reported that longterm adoption of CA encouraged diversity of Agrobacterium spp. and Pseudomonas spp. (Hoflich et al., 1999). Many similar studies conducted in different agro-ecological conditions and locations were resulted that CA had positive effects on soil microbial activities (Hassen et al., 2007). The lower levels of SOC which is most important for maintain vital functions and diversity of soil microbes, reported as key reason for lower functional diversity of soil microbes with CT. The similar results of lower soil microbial activity with decreased levels of SOC were also reported by Patra et al., 2008. Many reports suggested that residue buildup was also a reason for abundance of bacteria under CA (Hammesfahr et al., 2008 and CejaNavarro et al., 2010).

Being a sensitive bioindicator of soil quality as well as ecosystem services and their fundamental loci in soil food webs (Neher 
2001), the soil nematodes have been widely studied biological parameter of the soil (Yeates, 2003; Sanchez-Moreno et al., 2011), and used to analyze soil food web dynamics in ecosystems (Ferris and Matute, 2003; Briar et al., 2007; Sanchez Moreno et al., 2011 and DuPont et al., 2009). The impact assessment of tillage on nematode dynamics is relatively easy due to quick assessment about diversity, body weight and length therefore its used as descriptive indicators of soil quality (Fiscus and Neher, 2002; Ferris, 2010; Mills and Adl, 2011). Soil nematodes communities play a critical role in wider range of soil functions. The most of free-living nematodes communities are known for nutrient recycling and attributed for nearly one third of the total nitrogen mineralisation (Griffiths, 1994). Soil water have strong impact on functions of the soil nematodes as its act as a medium for their movement. Beside, soil moisture, their function and diversity largely susceptible to soil structure, porosity and compaction, and therefore soil tillage. However, the response of soil nematode communities to tillage can very not only with functional groups of nematode but also other factors such as the cropping and retention of crop residues (McSorley and Gallaher, 1995; LopezFando and Bello, 1995). For example, Zhang et al., (2012) reported that maximum nematode dynamics found under treatment that retained $100 \%$ crop residue followed by in treatments having $50 \%$ residue and least in residue removal for both no tillage and deep tillage. Moreover, specific genus of soil nematode found to be respond specific to particular tillage and residue management. For example, the direct abrasion and changes in soil structural change caused after mechanical manipulation of soil in case of tillage while their larger influence on various nutrient recycling in case of crop residue were known to different specific mechanism attributed for specific response of soil nematode communities (Kladivko, 2001 and Rahman et al., 2007). Reduced tillage resulted into higher numbers of nematodes and mites compared with conventional tillage and it proved that population as well as functions of soil microorganism can be limited through intensive soil tillage. However, soil nematodes and mites, responded deferentially to the tillage practices that may lead to reduction or stimulation (Wardle 1995). The differential respond of these organisms attributed due to type of soil, climate, location and tillage system chosen. Usually, the response of mite to tillage system is closely similar to soil nematodes therefore their dynamics in soil were greatly correlated with each other. As we know that in agroecosystem most soil nematodes are known as bacterial and fungal feeders and soil mites were fungivorous therefore they lies the tropic level immediately above bacteria and fungi (Carter et al., 2009).

\section{Mesofauna}

Mesofauna are known to play a critical role not only in improving soil fertility but also in stabilizing the soil structure by encouraging the rate of microaggregates formation of soil. Mesofauna represent a range of tropic levels and known to feed on plant litter and soil microbes (microflora and mesofauna) (Miyazawa et al., 2002). Potworms (Enchytraeidae), is known to share largest portion of mesofauna and its dynamics and function strongly depends on levels of SOC. Due to their small size and higher reproductive potential, the potworms diversity were reported to be unaffected by tillage (Didden et al., 1994). However, vertical distribution of potworm reported to strongly affected through tillage and under CA, they are most abundant near the soil surface but are more evenly distributed under CT ploughed fields. Springtails (Collembola) and Acari (mites) also play a critical role in nutrient recycling, especially, when organic 
manures were used as major source of nutrient that encourage their preferred fungal food (Reeleder et al., 2006). Due to their relatively larger size, they are more easily sampled so effects of tillage and crop rotations over their diversity and functions can be more visible (Wardle 1995). For example, ZT reduced the abundance of Collembola in sub surface soil (Moore et al., 1985). However, with ZT the population of Collembola and crypostigmatic mites was significantly higher at the soil surface (0-3 cm) (Vreeken-Buijs et al., 1994). Moreover, the vertical distribution of the microarthropods depends on soil tillage and compaction and $\mathrm{CA}$ practices reported with the higher density of macropores, which facilitating vertical distribution of microarthropods (Schrader and Lingnau, 1997).

Reeleder et al., 2006 reported that mite population in soil was more affected by crop rotation as compared to tillage practice, with higher populations in a system with a rye cover crop than in with fallow.

The effect of tillage practices and residue retention over mites population was reported to be variable and different groups of mites known to respond differently to tillage systems. It has been reported that the prostrigmatic, cryptostigmatid and mesostigmatid mites population were inhibited under CT compared CA practices. However, the diversity of astigmatid mites may be inhibited by tillage but known to recover within short span of time after tillage (Reeleder et al., 2006). Some individuals may killed by abrasion caused by extreme physical disturbance during intensive tillage operation or by being trapped in soil clods are after tillage (Kladivko, 2001) that leads to lower functional diversity of this group of microbes with CT.

\section{Macrofauna}

This group includes a range of microbes that known to be more sensitive to agro-ecosystem services (Chan 2001). Tillage, due to their large size had strong negative effect on their population through direct physical disruption as well as habitat destruction (Kladivko 2001). In addition, residue incorporation in case of CT further could limit recolonization of soil biota through redistribution of their food source as well as greater water and temperature fluctuations. Lumbricidae (earthworms) that represent a major group of macrofunna, known to modify the soils structure by the creation of burrows, which can control infiltration and drainage, and combined with the binding ability of casts, decrease the risk of erosion (Arden-Clarke and Hodges, 1987). Earthworms mainly engaged in mixing of organic matter and formation of humus, alter the nutrient dynamics, and encouraging microbial activity. Many studies suggested that earthworm diversity is directly affected through tillage practices, but the impact can varies with species, soil type, climate and type of tillage practices (Chan 2001). CT, that cause intensive soil inversion can exposes earthworms to predation and desiccation (House and Parmelee 1985) and known to cause more damage especially deep burrowing (anecic) species of earthworms (Kladivko et al., 2001). However, CA especially combined with residues retention has been reported to increase the earthworm diversity near soil surface (Kladivko, 2001). Earthworm casts associated with formation of stable organo-mineral complexes that promote soil macroaggregate stability and reduce loss of nutrients (Six et al., 2004). The activity of earthworm in soil is also reported to be directly correlated with infiltration and they improve it through enhanced soil surface roughness and increased soil macroporosity (Blanchart et al., 2004). Long term adoption 
of CA leads to significant enhancement in earthworm activity i.e. over 10 years it was $36 \%$ higher under CA compared CT (Jordan et al., 2000). CA practices shown their positive effect on earthworm populations under may be especially drier climates Pacific North West, whether earthworm activity was recorded six times higher after 30 years of adoption (Wuest, 2001). The gastropods, isopods and myriapods are other major member of macrofauna and being large in size, considered the most sensitive to tillage practices and as a result, they are present in soils subjected to deep tillage (Ekschmitt et al., 2005). These microbes are known to feed on green organic matter and their faeces encourage microbial activity leading to the formation of soil aggregates and humus. CA practices have reported to encouraged the functional diversity of these groups by as most of the crop residues remain available on the soil surface and physical structure is retained due to reduces soil disturbance which facilitating their movement within the soil. The soil also acts as a rich source of a range of predatory arthropods, especially the members of Coleoptera and Arachnida. Tillage has both direct effect (by causing mortality and indirect effects (by modifying their habitat and the availability of prey). Termites and ants respresent an important groups of siol microbes under arid and semiarid regions where earthworms are normally absent or scarce (Lobry de Bruyn and Conacher, 1990). In general, both ant as well as termites was reported to improve soil infiltration by enhancing soil aggregation and porosity (Nkem et al., 2000). Some group of termites also having tendency of feeding on soil and help in formation of microaggregates either through production of faecal pellets or by mixing the soil with saliva (Bignell, 2010). However, the amount of crop residue that incorporated or retained on the soil surface is act as main force which largely decide the stability of soil structure (Six et al., 2004).
Ants well known agent which can change soil bio-physico-chemical behaviour of soil by enhancing SOC turnover, causing pedoturbation and by reducing $\mathrm{Ca}, \mathrm{Mg}, \mathrm{K}$ and $\mathrm{Na}$ concentrations, especially in boundaries of their hills and paths in soil (Nkem et al., 2000). It has been hypothesized that nutrients stored in active mounds of ants are not readily accessible to plants as well as agents of soil organic matter decomposition, therefore ants cause redistribution of nutrients in the soil when their mound is abandoned. CA practices such as ZT in combination with proper residue retention have been recognised as key management practices which favour ants and termites populations in agro-ecosystems.

\section{Microbial biomass carbon (MBC)}

$\mathrm{MBC}$ is a breathing part of the soil organic matter which plays a critical role in nutrient transformation and not only a good source of carbon, nitrogen, phosphorus and sulfur but also improves the physico-chemical environment of soil (Angers et al., 1992). Continuous use of CA based management practices leads to reduction in soil disturbance which can stimulate soil microbial biomass and improve its metabolic rate, resulting in better soil quality, which in turn, can increase crop productivity (Hungria et al., 2009). These favorable effects of CA based tillage practices such as zero tillage; permanent bed planting and residue retention on soil microbial populations are mainly due to improved soil aeration, favorable soil microclimate, lower temperature and moisture fluctuations and higher accumulation of carbon in surface soil (Doran 1980). SalinasGarcia et al., 2002 reported that MBC were significantly affected by various crop establishment tillage, primarily into upper 0-5 $\mathrm{cm}$ soil surface which was $25-50 \%$ greater with ZT and minimum tillage than with CT. Likewise, Gonzalez-Chavez et al., (2010) reported that NT soils had nearly double 
contents of $\mathrm{MBC}$ and microbial biomass nitrogen as compared to CT. Dong et al., 2009 also reported that the mean annual MBC was highest in the ZT with residue, while lowest in CT without residue. Similarly, Silva et al., 2010 consistently found higher values of $\mathrm{MBC}$ and microbial biomass nitrogen up to more than $100 \%$ under NT in comparison to CT. NT soils with crop residue addition had more available substrates than $\mathrm{CT}$ and this promotes microbial growth and assimilation of nutrients, leading to an increase in soil microbial biomass and activity of such soils (Buyer et al., 2010). Cartert and Rennie, 1982 observed that the surface depth under zero tillage was enriched in MBC which was 14$28 \%$ higher in comparison to the corresponding depth under CT, while the reverse phenomenon was observed at lower depths.

\section{Soil enzymatic activity}

Tillage disturbs the natural state of soil and lower enzymatic activities would be expected under intensively tilled soils due to higher oxidation of soil organic matter under these crop management practices (Melero et al., 2011). CA based tillage increase the enzymatic activities in the soil profile, probably due to of similar vertical distribution of organic residues and microbial activity and these positively altered soil enzymes which play significant role in catalyzation of reactions obligatory for organic matter decomposition and nutrient cycling as well as involved in energy transfer, improvement of environmental quality and crop productivity (Dick, 1994).

Soil fluorescein di-acetate (FDA) hydrolysis is a measurement of the contribution of several enzymes, mainly involved in the decomposition of organic matter in soil. Hence, the higher the values of FDA hydrolysis are a sign of positive soil health and microbial activity. Vargas et al., 2009 had been noticed higher levels of fluorescein diacetate (FDA) hydrolysis under ZT than CT systems. Likewise, higher activities of FDA hydrolysis also noticed by Seifert et al., 2001. Soil Dehydrogenase (DH) enzymes are one of the main components of soil enzymatic activities participating in and assuring the correct sequence of all the biochemical routes in biogeochemical cycles (Ladd 1985).It is predominantly an intracellular enzyme, mainly used as an index of metabolic activity of microbial community in soil. Dehydrogenase activity represents the intracellular flux of electrons to $\mathrm{O}_{2}$ and is due to the activity of several intracellular enzymes catalyzing the transfer of hydrogen and electron from one compound to another (Nannipieri et al., 2003). Roldan et al., 2007 reported higher dehydrogenase and phosphatase in the $0-5 \mathrm{~cm}$ soil layer with ZT than CT. Likewise, Singh et al., 2009 reported that the dehydrogenase enzyme activity of soil under permanent bed planting method registered significantly higher $(62 \%)$ than CT. Another important soil enzyme is phosphatases which play a key role in phosphorous cycle by solubilizing organic and inorganic phosphates into available forms that increases the available phosphorus to crop plants (Wyszkowska and Wyszkowski 2010). Hota et al., 2014 noticed that incorporation of organic residues along with ZT showed greater acid phosphatase activities than the $\mathrm{CT}$ without residue.

In conclusion, CA improves soil aggregation compared to CT systems in a wide variety of soils and agro-ecological conditions. The conversion of $\mathrm{CT}$ to $\mathrm{CA}$ by adopting ZT/PB planting technology can result in lower soil BD. The reported research advocated a variable effect of $\mathrm{CA}$ on hydraulic soil properties therefore more research is needed to determine the effect of the adoption of CA on hydraulic soil properties in different soils 
and agro-ecological conditions. The combination of ZT with crop residue retention increases the SOC sequestration in soil. Especially when crop diversity and intensity are increased, evidence points to the validity of $\mathrm{CA}$ as a carbon storage practice and justifies further efforts in research and development. As the C-cycle is influenced by $\mathrm{CA}$ also the $\mathrm{N}$ cycle is altered. Adoption of CA systems with crop residue retention may result initially in $\mathrm{N}$ immobilization. However, rather than reducing $\mathrm{N}$ availability, $\mathrm{CA}$ may stimulate a gradual release of $\mathrm{N}$ in the long run and can reduce the susceptibility to leaching or dentrification when no growing crop is able to take advantage of the nutrients at the time of their release. Also crop diversification, an important component of $\mathrm{CA}$, has to be seen as an important strategy to govern $\mathrm{N}$ availability through rational sequences of crops with different $\mathrm{CN}$ ratios. Tillage, residue management and crop rotation have a significant impact on microand macronutrient distribution and transformation in the soil. The altered nutrient availability may be due to surface placement of crop residues in comparison with incorporation of crop residues with tillage. CA practices increases availability of nutrients near the soil surface where crop roots proliferate. Slower decomposition of surface placed residues prevents rapid leaching of nutrients through the soil profile. The response of soil chemical fertility to tillage is site-specific and depends on soil type, cropping systems, climate, fertilizer application and management practices. However, in general nutrient availability is related to the effects of CA on SOC. CA induces important shifts in soil fauna and flora communities. The different taxonomic groups of soil microbes respond differently to tillage disturbance and changed residue management strategies. The needed yield increases, production stability, reduced risks and environmental sustainability can only be achieved through management practices that result in an increased soil quality in combination with improved crop varieties. The above outlined evidence for the improved soil quality and production sustainability with well implemented CA systems is clear, although research remains inconclusive on some points. At the same time, the evidence for the degradation caused by tillage systems is convincing especially in tropical and subtropical conditions and for biological and physical soil quality. Therefore, even though we do not know how to manage functional CA systems under all conditions, the underlying principles of $\mathrm{CA}$ should provide the foundation upon which the development of new practices is based, rather than be considered a parallel option to mainstream research activities that focus on improving the current tillage-based production systems under diverse soil as well as ecological conditions.

\section{References}

Abdi, D., Cade-Menun, B.J., Ziadi, N. and Parent, L.É. 2014. Long-term impact of tillage practices and phosphorus fertilization on soil phosphorus forms as determined by $\mathrm{P}$ nuclear magnetic resonance spectroscopy. J. environ. Quality, 43(4): 1431-1441.

Amado, T.J.C., Bayer, C., Eltz, F.L.F. and Brum, A.C.R. 2001. Potential of cover crops to sequester carbon and increase soil nitrogen content, under no-tillage system, improving environmental quality. Rev. Bras. de Ciên. 25(1):189-197.

Anderson, T.H. 2003. Microbial eco-physiological indicators to asses soil quality. Agri. Eco. Environ., 98(1): 285-293.

Angers, D.A., Peasant, A. and Vigneux, J. 1992. Early cropping induced changes in soil aggregation, organic matter and microbial biomass. Soil Sci. Soc. Am. J., 56: 115-119.

Anikwe, M.A.N., and Ubochi, J.N. 2007. Short-term changes in soil properties under tillage systems and their effect on sweet potato (Ipomeabatatas L.) growth and yield in an Ultisol in south-eastern Nigeria. Australian J. Soil Res., 45: 351-358. 
Arden-Clarke, C. and Hodges, R.D. 1987. The environmental effects of conventional and organic/biological farming systems. I. Soil erosion, with special reference to Britain. Bio. Agri. Horti., 4(4):309-357.

Arshad, M.A. and Martin, S. 2002. Identifying critical limits for soil quality indicators in agro-ecosystems. Agri. Eco. Environ. 88(2):153-160.

Bai, Z.G., Dent, D.L., Olsson, L. and Schaepman, M.E. 2008. Proxy global assessment of land degradation. Soil Use and Manag. 24(3):223234.

Baker, C.J., Saxton, K.E., Ritchie, W.R., Chamen, W.C.T., Reicosky, D.C., Ribeiro, M.F.S., Justice, S.E. and Hobbs, P.R. No-tillage seeding in Conservation Agriculture. 2nd Edn., Food and Agriculture Organization, Rome and CAB International, Wallingford, UK, pp. 326.

Balota, E.L., ColozziFilho, A., Andrade, D.S. and Dick, R.P. 2004. Long-term tillage and crop rotation effects on microbial biomass and $\mathrm{C}$ and $\mathrm{N}$ mineralization in a Brazilian Oxisol. Soil Till Res., 77(2): 137-145.

Bayer, C., Mielniczuk, J., Amado, T.J.C., Martin, N.L. and Fernandes, S.V. 2000. Organic matter storage in a sandy loam Acrisol affected by tillage and cropping systems in southern Brazil. Soil Till Res., 54:101-109.

Beare, M.H., Cabrera, M.L., Hendrix, P.F. and Coleman, D.C. 1994. Aggregate-protected and unprotected organic-matter pools in conventional-tillage and no-tillage soils. Soil Sci. Soc. Am. J., 58: 787-795.

Bhattacharya, R., Prakash, V., Kundu, S. and Gupta, H.S. 2006. Effect of tillage and croprotations on pore size distribution and soil hydraulic conductivity in sandy clay loamsoil of the Indian Himalayas. Soil Till Res., 86: 129140 .

Bignell, D.E. 2010. Morphology, physiology, biochemistry and functional design of the termite gut: an evolutionary wonderland. In Biology of termites: a modern synthesis. Springer Netherlands, pp. 375-412.

Bissonette, N., Angers, O.A., Simard, R.R. and Lafond, J. 2001. Interactive effect ofmanagement practices on water stable aggregation and organic matter of humic Gleysol. Can. J. Soil Sci., 81: 545-551.

Biswas, A.K., Mohanty, M., Hati, K.M. and Misra, A.K. Distillery effluents effect on soil organic carbon and aggregate stability of a Vertisol in India. Soil Till Res., 2009; 104: 241-246.

Blanchart, E., Bernoux, M., Sarda, X., Siqueira Neto, M., Cerri, C.C., Piccolo, M., Douzet, J.M., Scopel, E. and Feller, C. Effect of direct seeding mulch-based systems on soil carbon storage and macrofauna in Central Brazil. Agri. Cons. Sci. 2007, 72(1):81-87.

Blanco-Canqui, H., Lal, R., Post, W.M., Izaurralde, R.C., and Owens, L.B.. Rapid changes in soil carbon and structural properties due to stover removal from no-till corn plots. Soil Sci. 2006, 171:468-482.

Bolliger, A., Magid, J., Amado, J.C.T., Neto, F.S., dos Santos Ribeiro, M.D.F., Calegari, A., Ralisch, R. and de Neergaard, A. Taking Stock of the Brazilian "Zero- Till Revolution": A Review of Landmark Research and Farmers' Practice. Adv. Agron. 2006, 91:47-110.

Borie, F., Rubio, R., Rouanet, J.L., Morales, A., Borie, G. and Rojas, C. Effects of tillage systems on soil characteristics, glomalin and mycorrhizalpropagules in a Chilean Ultisol. Soil Till Res 2006, 88(1):253-261.

Bradford, J.M. and Peterson, G.A. Conservation tillage. Handbook of soil science 2000, pp. 247-270.

Briar, S.S., Grewal, P.S., Somasekhar, N., Stinner, D. and Miller, S.A. Soil nematode community, organic matter, microbial biomass and nitrogen dynamics in field plots transitioning from conventional to organic management. Appl. Soil Eco. 2007, 37(3):256-266.

Bronick, C.J. and Lal, R. Soil structure and management: a review. Geod. 2005, 124:322.

Brussaard, L., De Ruiter, P.C. and Brown, G.G. Soil biodiversity for agricultural sustainability. Agri. Eco. Environ. 2007, 121(3):233-244.

Buyer, J.S., Teasdale, J.R., Roberts, D.P., Zasada, I.A. and Maul, J.E. Factors affecting soil microbial community structure in tomato cropping systems. Soil Bio. Biochem. 2010, 42: 831-841.

Calegari, A., Hargrove, W.L., Rheinheimer, D.D.S., Ralisch, R., Tessier, D., de Tourdonnet, S. and de Fatima Guimarães, M. Impact of longterm no-tillage and cropping system management on soil organic carbon in an Oxisol: a model for sustainability. Agron. J. 
2008, 100(4):1013-1019.

Carter, M.R. and Rennie, D.A. Changes in soil quality under zero tillage farming systems: distribution of microbial biomass and mineralizable $\mathrm{C}$ and $\mathrm{N}$ potentials. Can. J. Soil Sci. 1982, 62:587-597.

Carter, M.R., Noronha, C., Peters, R.D. and Kimpinski, J. Influence of conservation tillage and crop rotation on the resilience of an intensive long-term potato cropping system: Restoration of soil biological properties after the potato phase. Agri. Eco. Environ. 2009, 133(1):32-39.

Ceja-Navarro, J.A., Rivera, F.N., Patiño-Zúñiga, L., Govaerts, B., Marsch, R., Vila-Sanjurjo, A. and Dendooven, L. Molecular characterization of soil bacterial communities in contrasting zero tillage systems. Plant soil 2010, 329(1):127-137.

Chan, K.Y. An overview of some tillage impacts on earthworm population abundance and diversity-implications for functioning in soils. Soil Till Res 2001, 57(4):179-191.

Christensen, B.T. Physical fractionation of soil and structural and functional complexity in organic matter turnover. Eur. J. Soil Sci., 2001, 52(3): 345-353.

Christopher, S.F., Lal, R. and Mishra, U. Regional study of no-tillage effects on carbon sequestration in Midwestern United States. Soil Sci. Soc. Am. J. 2009, 73: 207-216.

Costanza, R., Norton, B.G. and Haskell, B.D. Ecosystem health: new goals for environmental management. Island Press, 1992.

Dao, T.H. Tillage and winter wheat residue management effects on water infiltration and storage. Soil Sci. Soc. Am. J. 1993, 57(6):1586-1595.

De Gryze, S., Six, J., Brits, C., and Merckx, R. A quantification of short-term macroaggregatedynamics: influences of wheat residue input and texture. Soil Bio. Biochem. 2005, 37:55-66.

De Oliveira, E.L. and Pavan, M.A. Control of soil acidity in no-tillage system for soybean production. Soil Till Res 1996, 38(1):47-57.

De, B.L. and Conacher, A.J. The role of termites and ants in soil modification-a review. Soil Res.1990, 28(1):55-93.

Dick, R.P. Soil enzymatic activities as indicators of soil quality. Defining Soil Quality for a sustainable environment Doran, J.W.,
Coleman, D.C., Bezdicek, D.F. and Stewart, B.A. (Eds.) 1994, pp.107-124.

Didden, W.A.M., Marinissen, J.C.Y., VreekenBuijs, M.J., Burgers, S.L.G.E., De Fluiter, R., Geurs, M. and Brussaard, L. Soil meso-and macrofauna in two agricultural systems: factors affecting population dynamics and evaluation of their role in carbon and nitrogen dynamics. Agri. Eco. Environ. 1994, 51(1):171-186.

Dogan, K., Celik, I., Gok, M. and Coskan, A. Effect of different soil tillage methods on rhizobial nodulation, biyomas and nitrogen content of second crop soybean. African J. Micro. Res 2011, 5(20):3186-3194.

Dong, W., Hu, C., Chen, S. and Zhang, Y. Tillage and residue management effects on soil carbon and $\mathrm{CO}_{2}$ emission in wheat-corn double cropping system. Nut. Cyc. Agroeco. 2009, 83: 27-37.

Doran, J.W. and Zeiss, M.R. Soil health and sustainability: managing the biotic component of soil quality. Appl. Soil Eco. 2000, 15(1):3-11.

Doran, J.W. Soil health and global sustainability: translating science into practice. Agri. Eco. Environ. 2002, 88(2):119-127.

Doran, J.W. Soil microbial and biochemical-changes associated with reduced tillage. Soil Sci. Soc. Am. J. 1980, 44: 765-771.

Du Preez, C.C. and Wiltshire, G.H. Changes in the organic matter and nutrient contents of some South African irrigated soils. South Afric. J. Plant Soil 1997, 14(2):49-53.

Du Preez, C.C., Steyn, J.T. and Kotze, E. Long-term effects of wheat residue management on some fertility indicators of a semi-arid Plinthosol. Soil Till Res 2001, 63(1):25-33.

Duiker, S.W. and Beegle, D.B. Soil fertility distributions in long-term no-till, chisel/disk and moldboard plow/disk systems. Soil Till Res 2006, 88(1):30-41.

DuPont, S.T., Ferris, H. and Van Horn, M. Effects of cover crop quality and quantity on nematodebased soil food webs and nutrient cycling. Appl. Soil Eco. 2009, 41(2):157-167.

Edwards, J.H., Wood, C.W., Thurlow, D.L. and Ruf, M.E. Tillage and crop rotation effects on fertility status of a Hapludult soil. Soil Sci. Soc. Am. J. 56(5):1577-1582.

Ekschmitt, K., Liu, M., Vetter, S., Fox, O. and Wolters, V., 2005. Strategies used by soil biota to overcome soil organic matter 
stability - why is dead organic matter left over in the soil?. Geod. 1992, 128(1):167176.

Erenstein, O. Crop residue mulching in tropical and semi-tropical countries: An evaluation of residue availability and other technological implications. Soil Till Res 2002, 67(2):115133.

Eynard, A., Schumacher, T.E., Lindstrom, M.J., and Maio, D.D. Porosity and pore-size distribution in cultivated ustolls and usterts. Soil Sci. Soc. Am. J. 2004, 68:1927-1934.

FAO. Conservation Agriculture. 2016.

Ferreira, M.C., Andrade, D.D.S., Chueire, L.M.D.O., Takemura, S.M. and Hungria, M. Tillage method and crop rotation effects on the population sizes and diversity of bradyrhizobia nodulating soybean. Soil Bio. Biochem. 2000, 32(5):627-637.

Ferris, H. and Matute, M.M. Structural and functional succession in the nematode fauna of a soil food web. Appl. Soil Eco. 2003, 23(2):93-110.

Ferris, H. Form and function: metabolic footprints of nematodes in the soil food web. Eur. J. Soil Bio. 2010, 46(2):97-104.

Filho, C.C., Lourenco, A., Guimaraes, F.M. and Fonseca, I.C.B. Aggregate stabilityunder different soil management systems in a red latosol in the state of Parana,Brazil. Soil Till Res 2002, 65:45-51.

Fiscus, D.A. and Neher, D.A. Distinguishing sensitivity of free- living soil nematode genera to physical and chemical disturbances. Eco. Appl. 2002, 12(2):565575.

Follett, R. and Schimel, D.S. Effect of tillage practices on microbial biomass dynamics. Soil Sci. Soc. A. J. 1989, 53(4):1091-1096.

Follett, R.F. Soil management concepts and carbon sequestration in cropland soils. Soil Till Res 2001, 61(1):77-92.

Franzluebbers, A.J. and Hons, F.M. Soil-profile distribution of primary and secondary plantavailable nutrients under conventional and no tillage. Soil Till Res 1996, 39(3):229-239.

Franzluebbers, A.J., Hons, F.M. and Zuberer, D.A. Tillage-induced seasonal changes in soil physical properties affecting soil $\mathrm{CO} 2$ evolution under intensive cropping. Soil Till Res 1995, 34(1):41-60.

Galantini, J.A., Landriscini, M.R., Iglesias, J.O.,
Miglierina, A.M. and Rosell, R.A. The effects of crop rotation and fertilization on wheat productivity in the Pampean semiarid region of Argentina: 2. Nutrient balance, yield and grain quality. Soil Till Res 2000, 53(2):137144.

Gathala, M.K., Ladha, J.K., Kumar, V., Saharawat, Y.S., Kumar, V., Sharma, P.K., Sharma, S., Pathak, H. Tillage and crop establishment affects sustainability of South Asian ricewheat system. Agron. J. 2011, 103:961-971.

Giller, P.S. River restoration: seeking ecological standards. Editor's introduction. J. Appl. Eco. 2005, 42(2):201-207.

González-Chávez, M.D.C.A., Aitkenhead-Peterson, J.A., Gentry, T.J., Zuberer, D., Hons, F. and Loeppert, R. Soil microbial community, C, N, and $\mathrm{P}$ responses to long-term tillage and crop rotation. Soil Till Res 2010, 106(2):285-293.

Govaerts, B., Mezzalama, M., Sayre, K.D., Crossa, J., Nicol, J.M. and Deckers, J. Long-term consequences of tillage, residue management, and crop rotation on maize/wheat root rot and nematode populations in subtropical highlands. Appl. Soil Eco. 2006, 32(3):305315 .

Govaerts, B., Sayre, K.D., Goudeseune, B., De Corte, P., Lichter, K.,Dendooven, L. and Deckers, J. Conservation agriculture as a sustainable option for the central Mexican highlands. Soil Till Res 2009, 103:222-230.

Govaerts, B., Sayre, K.D., Lichter, K., Dendooven, L. and Deckers, J. Influence ofpermanent bed planting and residue management on physical and chemical soilquality in rain fed maizewheat system. Plant Soil 2007, 291:39-54.

Graham, M.H., Haynes, R.J. and Meyer, J.H. Soil organic matter content and quality: effects of fertilizer applications, burning and trash retention on long-term sugarcane experiment in South Africa. Soil Bio. Biochem. 2002, 34(1):93-102.

Griffiths, B.S. Microbial-feeding nematodes and protozoa in soil: Their effects on microbial activity and nitrogen mineralization in decomposition hotspots and the rhizosphere. Plant Soil 1994:164(1):25-33.

Hadas, A., Agassi, M., Zhevelev, H., Kautsky, L., Levy, G.J., Fizik, E. and Gotessman, M.,. Mulching with composted municipal solid wastes in the Central Negev, Israel: II. Effect on available nitrogen and phosphorus and on organic matter in soil. Soil Till Res 2004, 
78(1):115-128.

Hammesfahr, U., Heuer, H., Manzke, B., Smalla, K. and Thiele-Bruhn, S. Impact of the antibiotic sulfadiazine and pig manure on the microbial community structure in agricultural soils. Soil Bio. Bio. 2008, 40(7):1583-1591.

Hassan, F.U., Ahmad, M., Ahmad, N. and Abbasi, M.K. Effects of subsoil compaction on yield and yield attributes of wheat in the sub-humid region of Pakistan. Soil Till Res 2007, 96(1):361-366.

Hawksworth, D.L. and Mound. Biodiversity databases: the crucial significance of collections. In: D.L. Hawksworth (Editor), The Biodiversity of Microorganisms and Invertebrates: Its Role in Sustainable Agriculture. CAB International 1991, pp1729.

Hawksworth, D.L. The fungal dimension of biodiversity: magnitude, significance, and conservation. Mycol. Res. 1991, 95(6):641655.

Hillel, O. Introduction to Environmental Soil Physical. Elsevier Science, Oxford, U.K. 2004.

Höflich, G., Tauschke, M., Kühn, G., Werner, K., Frielinghaus, M. and Höhn, W. Influence of long-term conservation tillage on soil and rhizosphere microorganisms. Bio.Fert. Soils 1999, 29(1):81-86.

Holland, J.M. The environmental consequences of adopting conservation tillage in Europe: reviewing the evidence. Agri. Eco. Environ. 2004, 103(1):1-25.

Hota, R., Jena, A.K. and Narayana, K.L. Effect of inorganic and organic amendments on yield of cocoyam (Colocasiaesculenta), and on soil properties. World J. Agri. Res. 2014, 2(2):7081.

House, G.J. and Parmelee, R.W. Comparison of soil arthropods and earthworms from conventional and no-tillage agroecosystems. Soil Till Res 1987, 55(4):351-360.

Hungria, M., Franchini, J.C., Junior, O.B., Kaschuk, G. and Souza, R.A. Soil microbial activity and crop sustainability in a long-term experiment with three soil-tillage and two crop-rotation systems. Appl. Soil Eco. 2009, 42:288-296.

Hussain, S., Arshad, M., Saleem, M. and Khalid, A. Biodegradation of $\alpha$-and $\beta$-endosulfan by soil bacteria. Biodeg. 2007, 18(6):731-740.

Ismail, I., Blevins, R.L. and Frye, W.W. Long-term no-tillage effects on soil properties and continuous corn yields. Soil Sci. Soc. Am. J. 1994, 58(1):193-198.

Janvier, C., Villeneuve, F., Alabouvette, C., EdelHermann, V., Mateille, T. and Steinberg, C. Soil health through soil disease suppression: which strategy from descriptors to indicators?. Soil Bio. Biochem. 2007, 39(1):123.

Jat R.A., Wani, P. and Kanwar, L.S. Conservation Agriculture in the Semi-Arid Tropics: Prospectsand Problems. Adv. Agron. 2012, 117:195-252.

Jat, M.L., Gathala, M.K., Saharawat, Y.S., Tetarwal, J.P., Gupta, R. and Yadvinder, S. Double notill and permanent raised beds in maizewheat rotation of north-western IndoGangetic plains of India: Effects on crop yields, water productivity, profitability and soil physical properties. Field Crop. Res. 2013, 149:291-299.

Jat, M.L., Srivastva, A., Sharma, S.K., Gupta, R.K., Zaidi, P.H. and Srinivasan, G. Evaluation of maize-wheat cropping system under doubleno-till practice in Indo-Gangetic plains of India. In $9^{\text {th }}$ Asian Regional Maize Workshop, Beijing, China, September 6-9, 2005.

Jinbo, Z., Changchun, S. and Shenmin, W. Dynamics of soil organic carbon and its fractions after abandonment of cultivated wetlands in northeast China. Soil Till Res 2007, 96(1):350-360.

Jordan, D., Hubbard, V.C., Ponder Jr, F. and Berry, E.C. The influence of soil compaction and the removal of organic matter on two native earthworms and soil properties in an oakhickory forest. Bio. Fert. Soils 2000, 31(3):323-328.

Kahlon, M.S., Lal, R. and Varughese, M. Twenty two years of tillage and mulching impacts on soil physical characteristics and carbon sequestration in Central Ohio. Soil Till Res 2013, 126:151-158

Karlen, D.L. and Stott, D.E. A framework for evaluating physical and chemical indicators of soil quality. Defining soil quality for a sustainable environment 1994, pp.53-72.

Kladivko, E.J. Tillage systems and soil ecology. Soil Till Res 2001, 61(1):61-76.

Kushwaha, C.P., Tripathi, S.K. and Singh, K.P. Variations in soil microbial biomass and $\mathrm{N}$ availability due to residue and tillage 
management in a dryland rice agroecosystem. Soil Till Res 2000, 56(3):153166.

Lal, R. Soil erosion and the global carbon budget. Environment International 2003, 29:437-450.

Li, L.L., Huang, G.B., Zhang, R.Z., Bill, R., Guangdi, L., Kwong, Y.C. Benefits of Conservation Agriculture on Soil and Water Conservation and Its Progress in China. Agri. Sci. China 2011, 10(6):850-859.

Lichter, K., Govaerts, B., Six, J., Sayre, K.D., Deckers, J. and Dendooven, L. Aggregation and $\mathrm{C}$ and $\mathrm{N}$ contents of soil organic matter fractions in a permanent raised-bed planting system in the Highlands of Central Mexico. Plant Soil 2008, 305(1)237-252.

Limon-Ortega, A., Govaerts, B., Deckers, J., and Sayre, K.D. Soil aggregate and microbial biomass in a permanent bed wheat-maize planting system after 12 years. Field Crop. Res. 2006, 97:302-309.

Limon-Ortega, A., Sayre, K.D., Drijber, R.A. and Francis, C.A. Soil attributes in a furrowirrigated bed planting system in northwest Mexico. Soil Till Res 2002, 63: 123-132.

López-Fando, C. and Bello, A. Variability in soil nematode populations due to tillage and crop rotation in semi-arid Mediterranean agrosystems. Soil Till Res 1995, 36(1):59-72.

Lupwayi, N.Z., Arshad, M.A., Rice, W.A. and Clayton, G.W. Bacterial diversity in waterstable aggregates of soils under conventional and zero tillage management. Appl. Soil Eco. 2001, 16(3):251-261.

Machado, P.L.O.A., Sohi, S.P. and Gaunt, J.L. Effect of no- tillage on turnover of organic matter in a Rhodic Ferralsol. Soil use manag. 2003, 19(3):250-256.

Madari, B., Machado, P.L.O.A., Torres, E., De, A.G. and Valencia, L.I.O.. No-tillageand crop rotation effects on soil aggregation and organic carbon in a Rhodic Ferralsol from southern Brazil. Soil Till Res 2005, 80: 185200.

Malhi, S.S., Nyborg, M., Goddard, T. and Puurveen, D. Long-term tillage, straw management and $\mathrm{N}$ fertilization effects on quantity and quality of organic $\mathrm{C}$ and $\mathrm{N}$ in a Black Chernozem soil. Nut. Cyc. Agroeco. 2011, 90(2):227-241.

Mando, A. and Miedema, R. Termite-induced change in soil structure after mulching degraded (crusted) soil in the Sahel. Appl. Soil Eco. 199, 76(3):241-249.
Marcolan, A.L., Anghinoni, I., Fraga, T.I. and Leite, J.G.D.B. Recovery of physicalattributes of an ultisol as affected by soil tillage and sowing time in no-tillage. Rev. Bras. Cien. 2007, 31(3):571-579.

McGarry, D., Bridge, B.J., and Radford, B.J. Contrasting soil physical properties after zero and traditional tillage of an alluvial soil in the semi-arid subtropics. Soil Till. Res 2000, 53:105-115.

McSorley, R. and Gallaher, R.N. Effect of yard waste compost on plant-parasitic nematode densities in vegetable crops. J. Nemat. 1995, 27(4):545-50.

Médiène, S., Valantin-Morison, M., Sarthou, J.P., de Tourdonnet, S., Gosme, M., Bertrand, M., Roger-Estrade, J., Aubertot, J.N., Rusch, A., Motisi, N. and Pelosi, C. Agroecosystem management and biotic interactions: a review. Agron. Sus. Dev. 2011, 31(3):491514.

Melero, S., Lopez-Bellido, R.J., Lopez-Bellido, L., Munoz-Romero, V., Moreno, F. and Murillo, J.M. Long-term effect of tillage, rotation and nitrogen fertiliser on soil quality in a Mediterranean Vertisol. Soil Till Res 2011, 114:97-107.

Mills, A.A.S. and Adl, M.S. Changes in nematode abundances and body length in response to management intensive grazing in a low-input temperate pasture. Soil Bio. Biochem. 2011, 43(1):150-158.

Miyazawa, K., Tsuji, H., Yamagata, M., Nakano, H. and Nakamoto, T. The effects of cropping systems and fallow managements on microarthropod populations. Plant Prod. Sci. 2002, 5(3):257-265.

Moore, J.C., St. John, T.V. and Coleman, D.C. Ingestion of vesicular-arbuscular mycorrhizal hyphae and spores by soil microarthropods. Eco. 1985, 66(6):1979-1981.

Nannipieri, P., Ascher, J., Ceccherini, M.T., Landi, L., Pietramellara, G. and Renella, G.. Microbial biodiversity and soil functions. Eur. J. Soil Sci. 2003, 54: 655-670.

Neher, D.A. Role of nematodes in soil health and their use as indicators. $J$ Nemat. 2001, 33(4):161-67.

Nicolardot, B., Recous, S. and Mary, B. Simulation of $\mathrm{C}$ and $\mathrm{N}$ mineralisation during crop residue decomposition: a simple dynamic model based on the $\mathrm{C}: \mathrm{N}$ ratio of the residues. Plant Soil 2001, 228(1):83-103. 
Nkem, J.N., de Bruyn, L.L., Grant, C.D. and Hulugalle, N.R.The impact of ant bioturbation and foraging activities on surrounding soil properties. Pedobio. 2000, 44(5):609-621.

Osunbitan, J.A., Oyedele, D.J., Adekalu, K.O. Tillage effects on bulk density,hydraulic conductivity and strength of a loamy sand soil in south-western Nigeria. Soil Till Res 2005, 82:57-64.

Parihar, C.M., Jat, S.L., Singh, A.K. and Jat, M.L. Energy scenario and Water and productivity of maize based cropping system under conservation agriculture practices in South Asia. In Proceeding of 5th World Congress on Conservation Agriculture, Incorporating the 3rd Farming systems Design Conference held at Brisbane, Australia from 26th to 29 Sept. 2011, pp.144-145.

Parihar, C.M., Yadav, M.R., Jat, S.L., Singh, A.K., Kumar, B., Pradhan, S., Chakraborty, D., Jat, M.L., Jat, R.K., Saharawat, Y.S. and Yadav, O.P. Long term effect of conservation agriculture inmaize rotations on total organic carbon, physical and biological properties of a sandy loam soil in north-western IndoGangeticPlains. Soil Till Res 2016, 161:11628.

Patra, A.K., Le Roux, X., Grayston, S.J., Loiseau, P. and Louault, F. Unraveling the effects of management regime and plant species on soil organic carbon and microbial phospholipid fatty acid profiles in grassland soils. Bio. Tech. 2008, 99(9):3545-3551.

Paustian, K., Six, J., Elliott, E.T. and Hunt, H.W. Management options for reducing $\mathrm{CO} 2$ emissions from agricultural soils. Biogeochem. 2000, 48(1):147-163.

Peng, X., Ye, L.L., Wang, C.H., Zhou, H. and Sun, B. Temperature-and duration-dependent rice straw-derived biochar: Characteristics and its effects on soil properties of an Ultisol in southern China. Soil Till Res, 2011, 112(2):159-166.

Piegholdt, C., Geisseler, D., Koch, H.J. and Ludwig, B. Long- term tillage effects on the distribution of phosphorus fractions of loess soils in Germany. J. Plant Nutr. Soil Sci. 2013, 176(2):217-226.

Pinheiro, E.F.M., Pereira, M.G., Anjos, L.H.C. Aggregate distribution and soilorganic matter under different tillage systems for vegetable crops in a red Latosolfrom Brazil. Soil Till
Res 2004, 77, 79-84.

Rahman, L., Chan, K.Y. and Heenan, D.P. Impact of tillage, stubble management and crop rotation on nematode populations in a long-term field experiment. Soil Till Res 2007, 95(1):110119.

Rahman, M.H., Okubo, A., Sugiyama, S. and Mayland, H.F. Physical, chemical and microbiological properties of an Andisol as related to land use and tillage practice. Soil Till Res 2008, 101(1):10-19.

Raimbault, B.A. and Vyn, T.J. Crop rotation and tillage effects on corn growth and soil structural stability. Agron. J. 1991, 83(6):979-985.

Rasmussen, K.J. Impact of ploughless soil tillage on yield and soil quality: a Scandinavian review. Soil Till Res 1999, 53(1):3-14.

Rasool, R., Kukal, S.S., Hira, G.S. Farmyard and inorganic fertilization effects onsaturated hydraulic conductivity of soil and performance of rice (Oryzasativa), wheat (Triticumaestivum) and maize (Zea mays) systems. Indian J. Agri. Sci. 2007, 77(11):768-771.

Rasse, D.P., Smucker, A.J.M. and Santos, D. Alfalfa root and shoot mulching effects onsoil hydraulic properties and aggregation. Soil Sci. Soc. Am. J. 2000, 64: 725-731.

Reeleder, R.D., Miller, J.J., Coelho, B.B. and Roy, R.C. Impacts of tillage, cover crop, and nitrogen on populations of earthworms, microarthropods, and soil fungi in a cultivated fragile soil. Appl. Soil Eco. 2006, 33(3):243-257.

Reicosky, D. and Archer, D.W. Moldboardplow tillage and short-term carbon dioxide release. Soil Till Res 2007, 94: 109-121.

Reicosky, D. Conservation Agriculture: Global environmental benefits of soil carbon management. In: García-Torres, L., Benítes, J., and Martínez-Vilela, A. (eds.) Conservation Agriculture -A Worldwide Challenge. 2001, pp 3-12.

Rice Wheat Consortium. RWC Research Highlights for 2005, http://www.rwc.cgiar.org.

Roldan, A., Salinas-Garcia, J.R., Alguacil, M.M. and Caravaca, F. Soil sustainability indicators following conservation tillage practices under subtropical maize and bean crops. Soil Till Res 2007, 93(2):273-282.

Salinas-Garcı， J.R., de J Velázquez -García， J., Gallardo-Valdez, M., Diaz-Mederos, P., 
Caballero-Hernández, F., Tapia-Vargas, L.M. and Rosales-Robles, E. Tillage effects on microbial biomass and nutrient distribution in soils under rain-fed corn production in central-western Mexico. Soil Till Res 2002, 66(2):143-152.

Sánchez-Moreno, S., Ferris, H., Young-Mathews, A., Culman, S.W. and Jackson, L.E. Abundance, diversity and connectance of soil food web channels along environmental gradients in an agricultural landscape. Soil Bio. Biochem. 2011, 43(12):2374-2383.

Schrader, S. and Lingnau, M. Influence of soil tillage and soil compaction on microarthropods in agricultural land. Pedobio. 1997, 41(1):202-209.

Sharma, A.R. and Behera, U.K. Recycling of legume residue for nitrogen economy andhigher productivity in maize (Zea mays)-wheat (Triticumaestivum) croppingsystem. Nut. Cyc. Agroeco. 2009, 83:197-210.

Silva, A.D., Babujia, L.C., Franchini, J.C., Souza, R.A. and Hungria. Microbial biomass under various soil and crop management systems in short and long-term experiments in Brazil. Field Crop. Res. 2010, 119: 20-26.

Singh, B. and Malhi, S.S. Response of soil physical properties to tillage and residue management on two soils in a cool temperate environment. Soil Till. Res 2006, 85:143-153.

Singh, G., Marwaha, T.S. and Kumar, D. Effect of resource-conserving techniques on soil microbiological parameters under long-term maize (Zea mays) - wheat (Triticum aestivum) crop rotation. Indian J. Agri. Sci. 2009, 79(2):94-100.

Singh, V.K., Dwivedi, B.S., Tiwari, K.N., Rani, M., Singh, S.K. and Timsina, J. Optimizing nutrient management strategies for ricewheat system in the Indo-Gangetic Plains of India and adjacent region for higher productivity, nutrient use efficiency and profits. Field Crop. Res. 2014, 164:30-44.

Six, J., Bossuyt, H., Degryze, S. and Denef, K. A history of research on the link between (micro) aggregates, soil biota, and soil organic matter dynamics. Soil Till Res 2004, 79(1):7-31.

Six, J., Conant, R.T., Paul, E.A. and Paustian, K. Stabilization mechanisms of soil organic matter: implications for C-saturation of soils. Plant soil 2002, 241(2):155-176.

Six, J., Guggenberger, G., Paustian, K., Haumaier,
L., Elliott, E.T., and Zech, W. Sources and composition of soil organic matter fractions between and within soil aggregates. Eur. J. Soil Sci. 2001, 52:607-618.

Six, J., Ogle, S.M., Breidt, F.J., Conant, R.T., Mosier, A.R. and Paustian, K. Thepotential to mitigate global warming with no-tillage management is only realizedwhen practised in the long term. Global Ch. Bio. 2004, 10:155-160.

Srinivasarao, C., Venkateswarlu, B., Lal, R., Singh, A.K., Kundu, S. Sustainable management of soils of dryland ecosystems of India for enhancing agronomic productivity and sequestering carbon. Adv. Agron. 2013, 121:253-325.

Stocking, M. A. and Murnaghan, N. Handbook for the field assessment of land degradation. Earthscan Publications Ltd., London. 2001.

Temme, A.J.A.M. and Verburg, P.H. Mapping and modelling of changes in agricultural intensity in Europe. Agri. Eco.Environ. 2011, 140(1):46-56.

Van Bruggen, A.H.C. and Semenov, A.M. In search of biological indicators for soil health and disease suppression. Appl. Soil Eco. 2000, 15(1):13-24.

Vargas, G.S., Meriles, J., Conforto, C., Figoni, G., Basanta, M., Lovera, E. and March, G.J. Field assessment of soil biological and chemical quality in response to crop management practices. World J. Mic. Biotech. 2009, 25(3):439-448.

Verheijen, F.G.A., Jones, R.J.A., Rickson, R. J. and Smith, C.J. Tolerable versus actual soil erosion rates in Europe. Earth-Sci. Rev. 2009, 94:1-4:23-38.

Verhulst, N., Govaerts, B., Verachtert, E., Castellanos-Navarrete, A., Mezzalama, M., Wall, P., Deckers, J. and Sayre, K.D. Conservation agriculture, improving soil quality for sustainable production systems. Advances in soil science: food security and soil quality 2010, pp.137-208.

Vreeken-Buijs, M.J., Hassink, J. and Brussaard, L. Relationships of soil microarthropod biomass with organic matter and pore size distribution in soils under different land use. Soil Bio. Biochem.1998, 30(1):97-106.

Wang, Q., Bai, Y., Gao, H., He, J., Chen, H., Chesney, R.C., Kuhn, N.J. and Li, H. Soil chemical properties and microbial biomass after 16 years of no-tillage farming on the 
Loess Plateau, China. Geod. 2008, 144(3):502-508.

Wang, X., Zhikuan, J. and Lianyou, L. Effect of straw incorporation on the temporal variations of water characteristics, water use efficiency and maize biomass production in semi-arid China. Soil Till Res 2015, 153:36-41.

Wardle, D.A. Impacts of disturbance on detritus food webs in agro-ecosystems of contrasting tillage and weed management practices. $A d v$. Eco. Res. 1995, 26:105-185.

Welch, R.M.The impact of mineral nutrients in food crops on global human health. Plant Soil 2002, 247:83-90

Wienhold, B.J., Andrews, S.S. and Karlen, D.L. Soil quality: a review of the science and experiences in the USA. Environ. Geochem. Health 2004, 26(2):89-95.

Wood, D. and Lenne, J.M. The conservation of agrobiodiversity on-farm: questioning the emerging paradigm. Biodiv. Con. 1997 6(1):109-129.

Wright, A.L. and Hons, F.M. Tillage impacts on soil aggregation and carbon and nitrogen sequestration under wheat cropping sequences. Soil Till Res 2005, 84(1): 67-75.

Wuest, S.B. Earthworm, infiltration, and tillage relationships in a dryland pea-wheat rotation. Appl. Soil Eco. 2001,18(2):187-192.

Wyszkowska, J. and Wyszkowski, M. Activity of soil dehydrogenase, urease, and acid and alkaline phosphatases in soil polluted with petroleum. J. Toxic. Environ. Health 2010, 73: 1202-1210.

Yadav, M.R., Parihar, C.M., Jat, S.L., Singh, A.K., Kumar D., Pooniya V., Parihar M.D., Saveipune, D., Parmar, H. and M.L. Jat.. Effect of long term tillage and diversified crop rotations on nutrient uptake, profitability and energetics of maize. Indian J. Agri. Sci. 2016, 86(6):743-749.

Yadav, M.R., Parihar, C.M., Kumar, R., Meena, R.K., Verma, A.P., Yadav, R.K., Ram H., Yadav, T., Singh M., Jat, S.L. and Sharma A. Performance of maize under conservation tillage 2016a, In. J. Agri. Sci. 8(39):18021805.

Yeates, G.W. Nematodes as soil indicators: functional and biodiversity aspects. Bio. Fert. Soil. 2003, 37(4):199-210.

Zagal, E. and Persson, J. Immobilization and remineralization of nitrate during glucose decomposition at four rates of nitrogen addition. Soil Bio. Biochem., 1994, 26(10):1313-1321.

Zhang, X., Li, Q., Zhu, A., Liang, W., Zhang, J. and Steinberger, Y. Effects of tillage and residue management on soil nematode communities in North China. Eco. Indicators, 2012, 13(1):75-81.

Zhao, H., Lv, Y., Wang, X., Zhang, H. and Yang, X. Tillage impacts on the fractions and compositions of soil organic carbon. Geod., 2012, 189: 397-403.

\section{How to cite this article:}

Yadav, M.R., C.M. Parihar, Rakesh Kumar, R.K. Yadav, S.L. Jat, A.K. Singh, H. Ram, R.K. Meena, M. Singh, V.K. Meena, N. Yadav, B. Yadav, C. Kumawat and Jat, M.L. 2017. Conservation Agriculture and Soil Quality- An Overview. Int.J.Curr.Microbiol.App.Sci. 6(2): 707-734. doi: http://dx.doi.org/10.20546/ijcmas.2017.602.080 